\title{
Turning Carbon Dioxide and Ethane into Ethanol by Solar-Driven Heterogeneous Photocatalysis over $\mathrm{RuO}_{2}$ - and $\mathrm{NiO}$-co-Doped $\mathrm{SrTiO}_{3}$
}

\author{
Larissa O. Paulista ${ }^{1}$, Josep Albero ${ }^{2}$, Ramiro J. E. Martins ${ }^{1}$, Rui A. R. Boaventura ${ }^{1} \mathbb{D}$, Vítor J. P. Vilar ${ }^{1} \mathbb{D}$, \\ Tânia F. C. V. Silva ${ }^{1, *}$ and Hermenegildo García ${ }^{2, *}$ D
}

1 Laboratory of Separation and Reaction Engineering-Laboratory of Catalysis and Materials (LSRE-LCM), Departamento de Engenharia Química, Faculdade de Engenharia, Universidade do Porto, Rua Dr. Roberto Frias, 4200-465 Porto, Portugal; larissa@fe.up.pt (L.O.P.); rmartins@ipb.pt (R.J.E.M.); bventura@fe.up.pt (R.A.R.B.); vilar@fe.up.pt (V.J.P.V.)

2 Instituto Universitario de Tecnología Química CSIC-UPV, Universidad Politécnica de Valencia, Av. de los Naranjos s/n, 46022 Valencia, Spain; joalsan6@upvnet.upv.es

* Correspondence: tania.silva@fe.up.pt (T.F.C.V.S.); hgarcia@qim.upv.es (H.G.); Tel.: +351-220414911 (T.F.C.V.S.); +34-963877807 (H.G.)

check for updates

Citation: Paulista, L.O.; Albero, J.; Martins, R.J.E.; Boaventura, R.A.R.; Vilar, V.J.P.; Silva, T.F.C.V.; García, H. Turning Carbon Dioxide and Ethane into Ethanol by Solar-Driven Heterogeneous Photocatalysis over $\mathrm{RuO}_{2}$ - and NiO-co-Doped $\mathrm{SrTiO}_{3}$ Catalysts 2021, 11, 461. https:// doi.org/10.3390/catal11040461

Academic Editor: Fernando Fresno

Received: 9 March 2021

Accepted: 30 March 2021

Published: 1 April 2021

Publisher's Note: MDPI stays neutral with regard to jurisdictional claims in published maps and institutional affiliations.

Copyright: (c) 2021 by the authors. Licensee MDPI, Basel, Switzerland. This article is an open access article distributed under the terms and conditions of the Creative Commons Attribution (CC BY) license (https:// creativecommons.org/licenses/by/ $4.0 /)$.
Abstract: The current work focused on the sunlight-driven thermo-photocatalytic reduction of carbon dioxide $\left(\mathrm{CO}_{2}\right)$, the primary greenhouse gas, by ethane $\left(\mathrm{C}_{2} \mathrm{H}_{6}\right)$, the second most abundant element in shale gas, aiming at the generation of ethanol $(\mathrm{EtOH})$, a renewable fuel. To promote this process, a hybrid catalyst was prepared and properly characterized, comprising of strontium titanate $\left(\mathrm{SrTiO}_{3}\right)$ co-doped with ruthenium oxide $\left(\mathrm{RuO}_{2}\right)$ and nickel oxide $(\mathrm{NiO})$. The photocatalytic activity towards $\mathrm{EtOH}$ production was assessed in batch-mode and at gas-phase, under the influence of different conditions: (i) dopant loading; (ii) temperature; (iii) optical radiation wavelength; (vi) consecutive uses; and (v) electron scavenger addition. From the results here obtained, it was found that: (i) the functionalization of the $\mathrm{SrTiO}_{3}$ with $\mathrm{RuO}_{2}$ and $\mathrm{NiO}$ allows the visible light harvest and narrows the band gap energy (ca. 14-20\%); (ii) the selectivity towards $\mathrm{EtOH}$ depends on the presence of $\mathrm{Ni}$ and irradiation; (iii) the catalyst photoresponse is mainly due to the visible photons; (iv) the photocatalyst loses $>50 \%$ efficiency right after the 2nd use; (v) the reaction mechanism is based on the photogenerated electron-hole pair charge separation; and (vi) a maximum yield of $64 \mu \mathrm{mol}$ EtOH g gat ${ }^{-1}$ was obtained after $45-\mathrm{min}\left(85 \mu \mathrm{mol} \mathrm{EtOH} \mathrm{g} \mathrm{gat}^{-1} \mathrm{~h}^{-1}\right)$ of simulated solar irradiation $\left(1000 \mathrm{~W} \mathrm{~m}^{-2}\right)$ at $200{ }^{\circ} \mathrm{C}$, using $0.4 \mathrm{~g} \mathrm{~L}^{-1}$ of $\mathrm{SrTiO}_{3}: \mathrm{RuO}_{2}: \mathrm{NiO}(0.8 \mathrm{wt} . \% \mathrm{Ru})$ with $\left[\mathrm{CO}_{2}\right]:\left[\mathrm{C}_{2} \mathrm{H}_{6}\right]$ and [Ru]:[Ni] molar ratios of 1:3 and 1:1, respectively. Notwithstanding, despite its exploratory nature, this study offers an alternative route to solar fuels' synthesis from the underutilized $\mathrm{C}_{2} \mathrm{H}_{6}$ and $\mathrm{CO}_{2}$.

Keywords: heterogeneous thermo-photocatalysis; solar fuels synthesis; hybrid perovskite catalyst; double doping approach; $\mathrm{CO}_{2}$ photoconversion; ethane upgrading

\section{Introduction}

The global economy has been moving towards an ever-growing consumption of fossil fuels, together with the emission of anthropogenic greenhouse gases, which has led to an energy crisis and global warming. Therefore, the development of promising strategies aiming at the carbon dioxide $\left(\mathrm{CO}_{2}\right)$ chemical conversion into renewable hydrocarbon fuels is urgent. In fact, Intergovernmental Panel on Climate Change (IPCC) has already reported the necessity for new options in the direction of 'negative emissions', even including the carbon dioxide removal (CDR) from the atmosphere targeting the global warming mitigation. Some advances have been made in the field of heterogeneous catalysis for the reduction of $\mathrm{CO}_{2}$, the main greenhouse gas. Still, many of the studies have predominantly focused on synthesizing chemical intermediates, such as syngas $\left(\mathrm{CO}+\mathrm{H}_{2}\right)$, alkenes, and aromatic compounds [1-4]. Furthermore, the transport and storage of syngas and alkenes 
raise potential safety risks, due to the high toxicity range and flammability of these gases, respectively $[5,6]$. Nonetheless, a lack of feasible approaches to produce valuable and safer oxygenate molecules directly from $\mathrm{CO}_{2}$ and other high environmental concern gases, such as shale gas, appears to exist.

A recent study performed by Xie et al. [7] has proposed a tandem reactor strategy that enables the synthesis of oxygenates (aldehydes and alcohols) by inserting the $\mathrm{CO}$ moiety from the $\mathrm{CO}_{2}$ into alkenes generated from the underutilized ethane $\left(\mathrm{C}_{2} \mathrm{H}_{6}\right)$, the shale gas second-largest component. This strategy comprised two stages: (i) one, where syngas and ethylene were generated through catalyzed $\mathrm{CO}_{2}$-assisted dehydrogenation and $\mathrm{C}_{2} \mathrm{H}_{6}$ reforming at $600-800{ }^{\circ} \mathrm{C}$; and (ii) a further one, where the readily-generated syngas and ethylene were used in a catalyzed hydroformylation reaction at $200{ }^{\circ} \mathrm{C}$ to produce propanal and/or 1-propanol. Additionally, other reactions of $\mathrm{CO}_{2}$ with $\mathrm{C}_{2} \mathrm{H}_{6}$ can also occur, including [8]: (i) oxidative dehydrogenation of ethane with $\mathrm{CO}_{2}$; (ii) non-oxidative dehydrogenation, (iii) cracking to form methane, and (iv) reverse water gas shift to produce water. So, depending on the catalyst proprieties and the reaction conditions, it is possible to foresee the synthesis of oxygenated compounds from the interaction between the $\mathrm{CO}_{2}$ and ethane molecules in a single unit. However, as $\mathrm{CO}_{2}$ is an extremely stable molecule, the catalytic processes' performance demands high temperature. Hopefully, this drawback can be compensated by employing thermo-photocatalysis [8-11].

Despite the several efforts made over the past few years towards photocatalytic reduction, the $\mathrm{CO}_{2}$ conversion still suffers from very low efficiencies. However, the photocatalytic activity can be enhanced through the structural engineering of photocatalysts with different architectures and surface properties (e.g., bandgap engineering, nanostructuralization, macro/meso/microporous structuralization, etc.) [1,12-14]. Among the perovskite semiconductors, strontium titanate $\left(\mathrm{SrTiO}_{3}\right)$ is a promising photocatalyst for $\mathrm{CO}_{2}$ reduction because of its semiconducting proprieties, high thermal and photochemical stability, negligible toxicity, and low cost [15]. Besides, the surface defects of the $\mathrm{SrTiO}_{3}$, such as oxygen vacancy, can act as an electron trap, as well as a $\mathrm{CO}_{2}$ absorption site [16]. There are precedents in the literature reporting that $\mathrm{SrTiO}_{3}$ semiconductor modified by means of co-doping gives rise to highly efficient photocatalyst capable of enhancing hydrogen evolution [17-20]. The doping process with metals can change the semiconductor's optical and electronic proprieties through up-shift in the valence band (VB), or down-shift in the conduction band (CB), or even induce doping levels within the forbidden band. On that account, the photocatalyst may be enhanced regarding the photoresponse to visible light, the product selectivity, and the efficiency for $\mathrm{CO}_{2}$ photoreduction [14]. A double doping approach using nickel (Ni) and ruthenium $(\mathrm{Ru})$ transition metals can improve the photocatalytic activity and selectivity in the UV-visible region by changing the semiconductor's electronic structure $[17,21]$. Meanwhile, the nickel can act as an electron trap, suppressing the electron-hole pair recombination and, consequently, boosting the $\mathrm{CO}_{2}$ photoconversion effectiveness [22]. Moreover, the harmless $\mathrm{Ni}^{2+}$ is an important species as it concerns the co-doping with high-valence ions, since it maintains the charge balance and increases the photocatalytic performance $[17,20]$.

To the best of our knowledge, there is only one study addressing the outstanding adeptness of the $\mathrm{SrTiO}_{3}$ co-doped with $\mathrm{RuO}_{2}$ and $\mathrm{NiO}$, but as a photocatalyst on nitrogen fixation with water pursuing ammonia synthesis [23]. Also, as far as we know, there are no reports on literature regarding the thermo-photocatalytic conversion of $\mathrm{CO}_{2}$ and $\mathrm{C}_{2} \mathrm{H}_{6}$ into value-added oxygenate molecules. Accordingly, this study aims to contribute to this growing area of research by exploring the performance of the hybrid $\mathrm{SrTiO}_{3}: \mathrm{RuO}_{2}: \mathrm{NiO}$ catalyst towards ethanol production $(\mathrm{EtOH})$ from $\mathrm{CO}_{2}$ and $\mathrm{C}_{2} \mathrm{H}_{6}$, using solar-driven heterogeneous thermo-photocatalysis. The photocatalytic activity was evaluated at gasphase under batch operation mode as a function of (i) photocatalyst composition, in terms of Ru and Ni loading; (ii) photothermal response; (iii) photoresponsiveness, under different optical radiation wavelength; (iv) photocatalyst reuse; and (v) the sacrificial agent addition, in a perspective of understanding the reaction mechanism. 


\section{Results}

\subsection{Characterization of the Photocatalysts}

The photocatalyst, used in the thermo-photocatalytic reduction of $\mathrm{CO}_{2}$ with ethane, was obtained by functionalizing of commercial $\mathrm{SrTiO}_{3}$ through a double doping approach with $\mathrm{RuO}_{2}$ and $\mathrm{NiO}$, as illustrated in Figure 1 and further described in the materials and methods section. To understand the structural and morphological changes on the $\mathrm{SrTiO}_{3}: \mathrm{RuO}_{2}: \mathrm{NiO}$ photocatalyst, several characterization techniques were used, namely: (i) UV-Vis diffuse reflectance spectroscopy (DRS), which was also applied for $\mathrm{SrTiO}_{3}$ and $\mathrm{SrTiO}_{3}: \mathrm{Ru}_{2}$ intermediate samples (Figure 2); (ii) X-ray diffraction (XRD) and Raman spectroscopy (Figure 3); (iii) energy-dispersive X-ray spectroscopy (EDS) mapping and transition electron microscopy (TEM) (Figure 4); and (iv) X-ray photoelectron spectroscopy (XPS) (Figure 5).

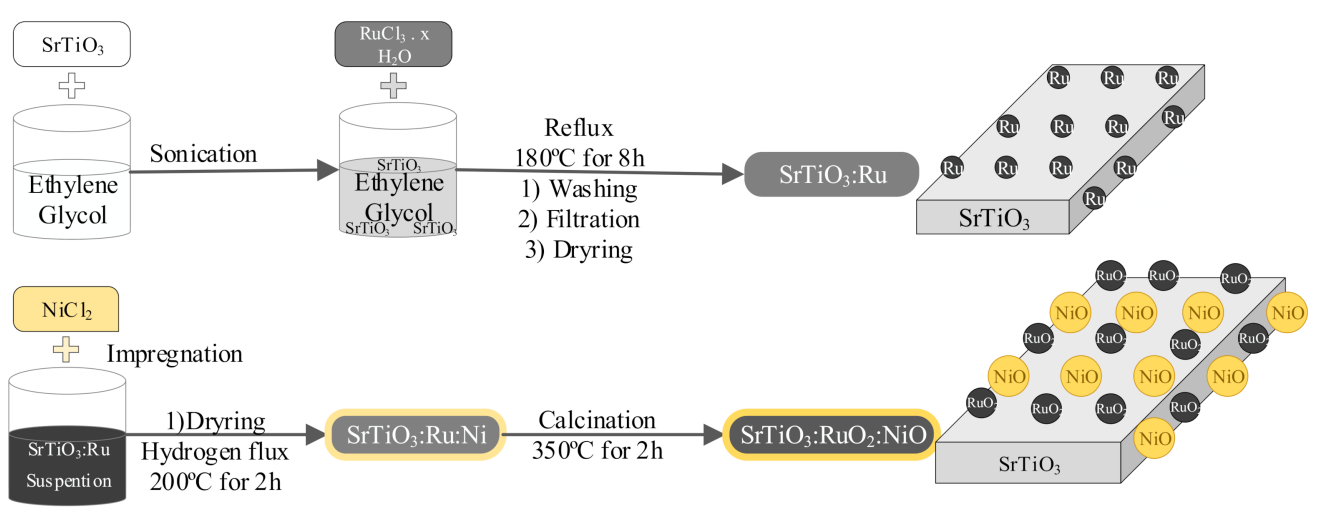

Figure 1. Schematic representation of the $\mathrm{SrTiO}_{2}: \mathrm{RuO}_{2}: \mathrm{NiO}$ photocatalyst preparation method.

Figure 2 depicts the UV-Vis DRS spectra (Figure 2a-c) and the optical band gap energy (Eg) (Figure 2d) of the $\mathrm{SrTiO}_{3}, \mathrm{SrTiO}_{3}: \mathrm{Ru}$ and $\mathrm{SrTiO}_{3}: \mathrm{RuO}_{2}: \mathrm{NiO}$ samples, where it is possible to verify that: (i) the pristine $\mathrm{SrTiO}_{3}$ presented a characteristic absorption band in the UV light region and the highest Eg value of ca. $3.2 \mathrm{eV}$ (estimated through the application of Kubelka-Munk method [24]) in accordance with the literature [25], with an absorption edge around $380-390 \mathrm{~nm}$, corroborating the need towards a spectral red-shift; (ii) the decoration of the $\mathrm{SrTiO}_{3}$ with $\mathrm{Ru}$ nanoparticles indeed increased the response against the visible irradiation since the Eg values decreased by about 8-14\%, compared to $\mathrm{SrTiO}_{3}$, resulting in a wide absorption band between $400-800 \mathrm{~nm}$ due to the $\mathrm{RuO}_{2}$ plasmon band, as also recorded Mateo et al. [21]; (iii) the impregnation with nickel further increased the visible light harvest, mainly after $520 \mathrm{~nm}$ through the ion transition level [26], and narrowed the Eg between $14-20 \%$, compared to $\mathrm{SrTiO}_{3}$; (iv) the global spectrum intensity progressively increased as the dopant concentration raised; (v) the Eg values did not follow a gradual decay pattern as the metal oxides' concentration increase, since the presence of excessive ions can induce intrinsic point defects, or oxygen vacancies, on the surface of metal-doped semiconductors, which may act as recombination centers [27,28]; and (vi) the double doping approach led to a partial suppression of the higher energy ions, resulting in a photocatalyst with weaker UV light absorption between $200-400 \mathrm{~nm}$, when compared to Ru-doped $\mathrm{SrTiO}_{3}$, as similarly reported for the co-doping of $\mathrm{SrTiO}_{3}$ with $\mathrm{Ni}$ and $\mathrm{Ta} / \mathrm{La}[17,20,29]$.

Based on the XRD pattern (Figure 3), it can be observed that the $\mathrm{SrTiO}_{3}: \mathrm{RuO}_{2}: \mathrm{NiO}$ photocatalyst actually features the characteristic diffraction peaks of the $\mathrm{SrTiO}_{3}, \mathrm{RuO}_{2}$ and $\mathrm{NiO}$ compounds, as expected. Moreover, it can also be inferred that the Ru and Ni metallic species were effectively oxidized on the semiconductor surface since the corresponding diffraction peaks matched with the $\mathrm{RuO}_{2}$ and NiO reference XRD patterns (JCPDS 01-0702662 and JCPDS 78-0643, respectively). From the Rietveld refinement, the sample reflection peaks were indexed to the tetragonal crystal system, with unit-cell lattice constants of a 
$=\mathrm{b}=3.874 \AA$ and $\mathrm{c}=12.720 \AA$ and axial angles of $\alpha=\beta=\gamma=90^{\circ}$ (estimated through Match! software). Conversely, the reference reflection peaks (JCPDS 35-0734) of the main photocatalyst component, the $\mathrm{SrTiO}_{3}$, are indexed to a cubic crystal system $(\alpha=\beta=\gamma=$ $90^{\circ}$ ) with standard lattice parameter values of $\mathrm{a}=\mathrm{b}=\mathrm{c}=3.905 \AA$ [ [30].
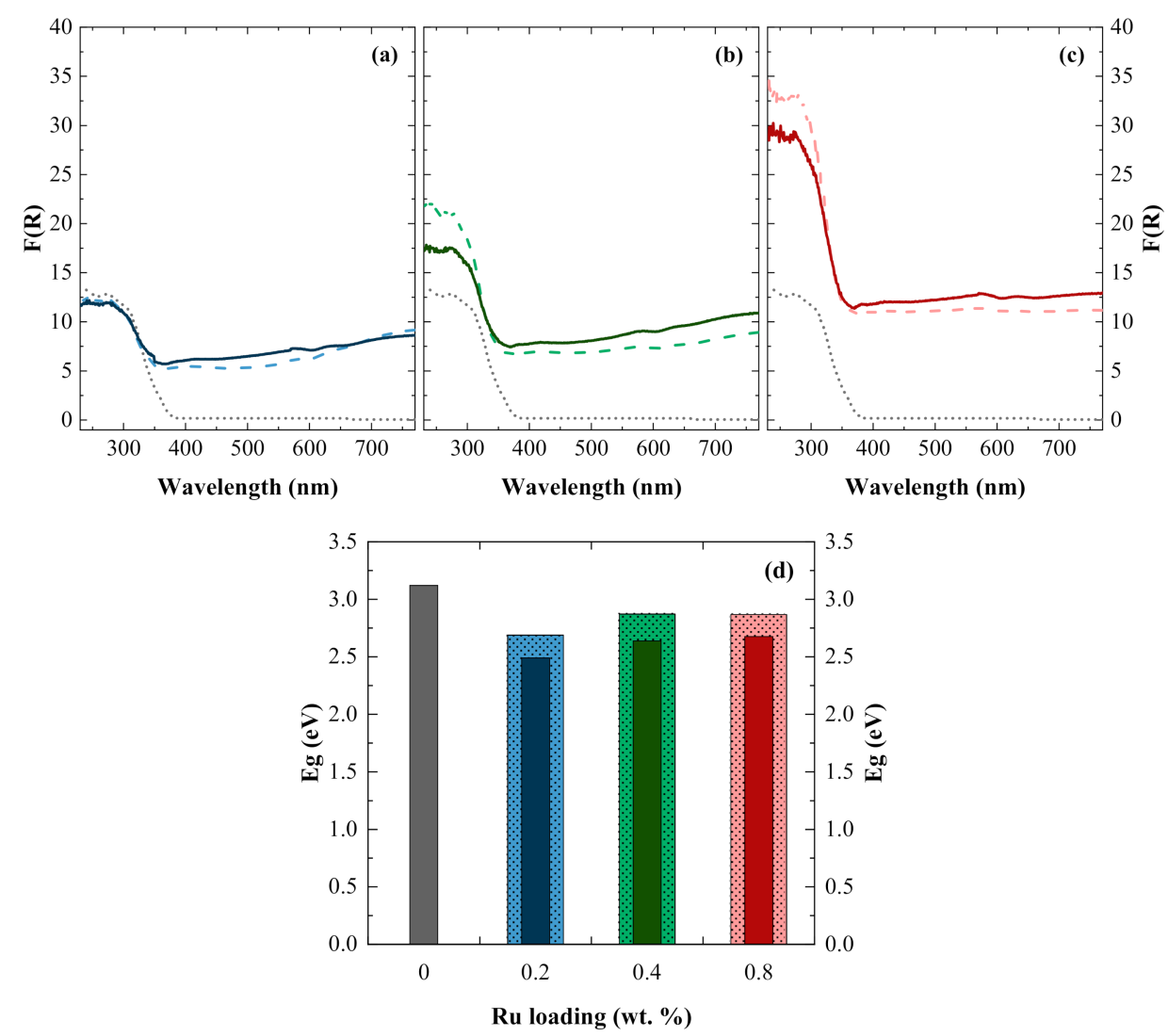

Figure 2. (a-c) UV-Vis diffuse reflectance spectra, represented as a Kubelka-Munk function of the reflectance- $-\mathrm{F}(\mathrm{R})$, and (d) optical band gap energy $(\mathrm{Eg})$ for undoped $\mathrm{SrTiO}_{3}$ (dotted lines, darker solid bar), Ru-doped $\mathrm{SrTiO}_{3}$ (dashed lines, patterned bars) and $\mathrm{Ru}$ and $\mathrm{Ni}$ co-doped $\mathrm{SrTiO}_{3}$ (solid lines, colored solid bars) photocatalysts, using Ru concentrations of (a) $0.2 \mathrm{wt}$ \%, (b) $0.4 \mathrm{wt}$. \%, and (c) 0.8 wt. $\%$ and a [Ru]:[Ni] molar ratio of $1: 1$.

The change on the perovskite crystalline structure suggests that the tetragonal lattices of the composed $\mathrm{SrTiO}_{3}: \mathrm{RuO}_{2}: \mathrm{NiO}$ photocatalyst are mainly a consequence of the $\mathrm{SrTiO}_{3}$ semiconductor cubic lattice stretching along the $\mathrm{c}$ lattice vector, most likely across the co-doping process with the metallic species. This cubic-to-tetragonal transition can be associated with oxygen's octahedral rotation around the $c$ axis [31]. Furthermore, given the similarity between the atomic radius of $\mathrm{Ru}$ and $\mathrm{Ti}$ (0.056 and $0.060 \mathrm{~nm}$, respectively) [32], it could be assumed that the $\mathrm{Ru}$ atom was incorporated into the host $\mathrm{SrTiO}_{3}$ lattice, thus also interfering with the lattice's crystallinity. Finally, the photocatalyst's crystallite size was estimated according to Scherrer's equation [33,34], considering all diffraction XRD peaks. It was found out that the crystallite size ranged between 4.4 and $36.9 \mathrm{~nm}$, presenting an average of $21.3 \mathrm{~nm}$. This lack of uniformity observed on the crystallite's size distribution can be attributed to the production of more lattice defects and lattice strains in the post-codoping thin films $[35,36]$.

The double doping process was also confirmed by the Raman microscopic spectrum (Figure 3: inset), which presents two characteristic $\mathrm{E}_{\mathrm{g}}\left(507 \mathrm{~cm}^{-1}\right)$ and $\mathrm{A}_{1 \mathrm{~g}}\left(618 \mathrm{~cm}^{-1}\right)$ bands, depicting the interaction of $\mathrm{RuO}_{2}: \mathrm{NiO}$ with the $\mathrm{SrTiO}_{3}$, as described by Álvarez et al. [37]. The insertion of the $\mathrm{Ni}^{2+}$ atom into the $\mathrm{RuO}_{2}$ lattice might have led to the variation in the Raman spectrum. Thence, a single wideband at $507 \mathrm{~cm}^{-1}$ was overlapped 
to the longitudinal order $(\mathrm{LO})$ photon mode and $\mathrm{E}_{\mathrm{g}}$ active mode corresponding to $\mathrm{NiO}$ and $\mathrm{RuO}_{2}$, respectively. Consequently, there was stress on the $\mathrm{RuO}_{2}$ lattice parameters, driving to the weakening of the $\mathrm{A}_{1 \mathrm{~g}}$ band (Figure 3: inset).

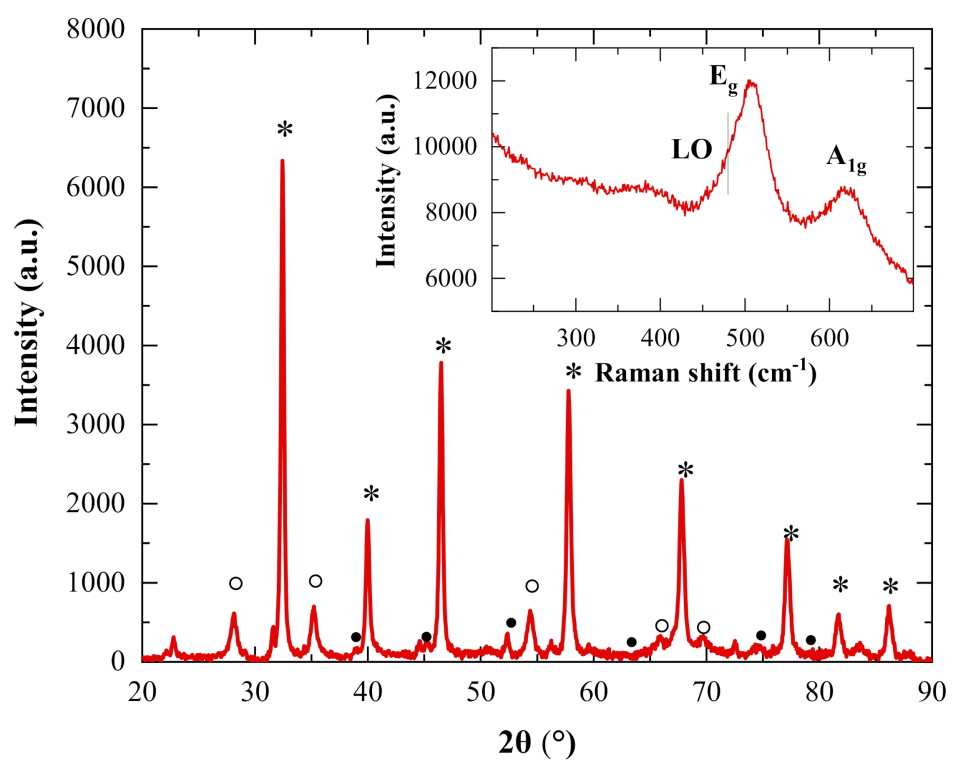

Figure 3. XRD pattern and Raman spectrum (inset) for $\mathrm{SrTiO}_{3}: \mathrm{RuO}_{2}: \mathrm{NiO}$ photocatalyst $(0.8 \mathrm{wt}$. \% of $\mathrm{Ru} ;[\mathrm{Ru}]:[\mathrm{Ni}]$ molar ratio of $1: 1)$. XRD diffraction peaks corresponding to either $\mathrm{SrTiO}_{3}\left({ }^{*}\right), \mathrm{RuO}_{2}\left({ }^{\circ}\right)$, and $\mathrm{NiO}(\bullet)$.

The TEM micrographs (Figure 4) display agglomerates of uneven particles, which corroborates with the crystallite size distribution obtained from the XRD characterization, presenting a spherical-like morphology, sized between $60-90 \mathrm{~nm}$, surrounded by smaller spherical-like particles, sized around 4-6 nm, corresponding to the $\mathrm{SrTiO}_{3}$ semiconductor (in agreement with the commercial specifications) and Ni and Ru metals, respectively. As expected, EDS mapping (Figure 4) confirms the presence of all elements used in the preparation of the photocatalyst, such as $\mathrm{Sr}, \mathrm{Ti}$, O, belonged to the $\mathrm{SrTiO}_{3}$ main compound, along with $\mathrm{Ni}$ and $\mathrm{Ru}$ metallic particles, whose existence are ascribed to the semiconductor co-doping process.

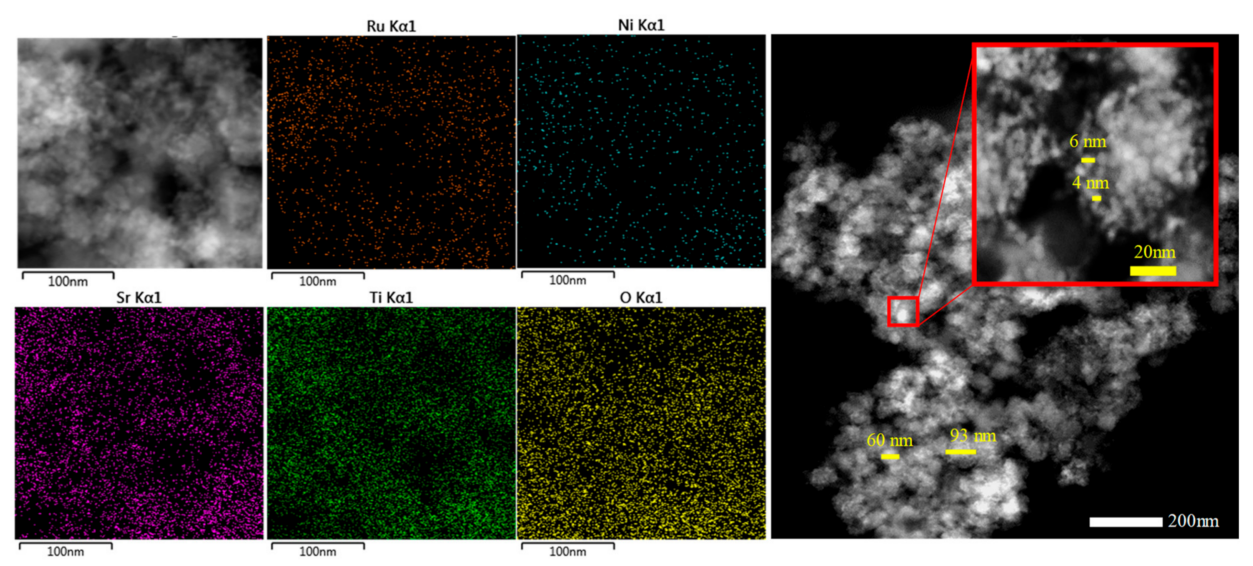

Figure 4. EDS elemental mapping $(\mathrm{Sr}, \mathrm{Ti}, \mathrm{O}, \mathrm{Ru}, \mathrm{Ni})$ and TEM images for $\mathrm{SrTiO}_{3}: \mathrm{RuO}_{2}: \mathrm{NiO}$ photocatalyst (0.8 wt. \% of $\mathrm{Ru}$; [Ru]:[Ni] molar ratio of $1: 1)$. 

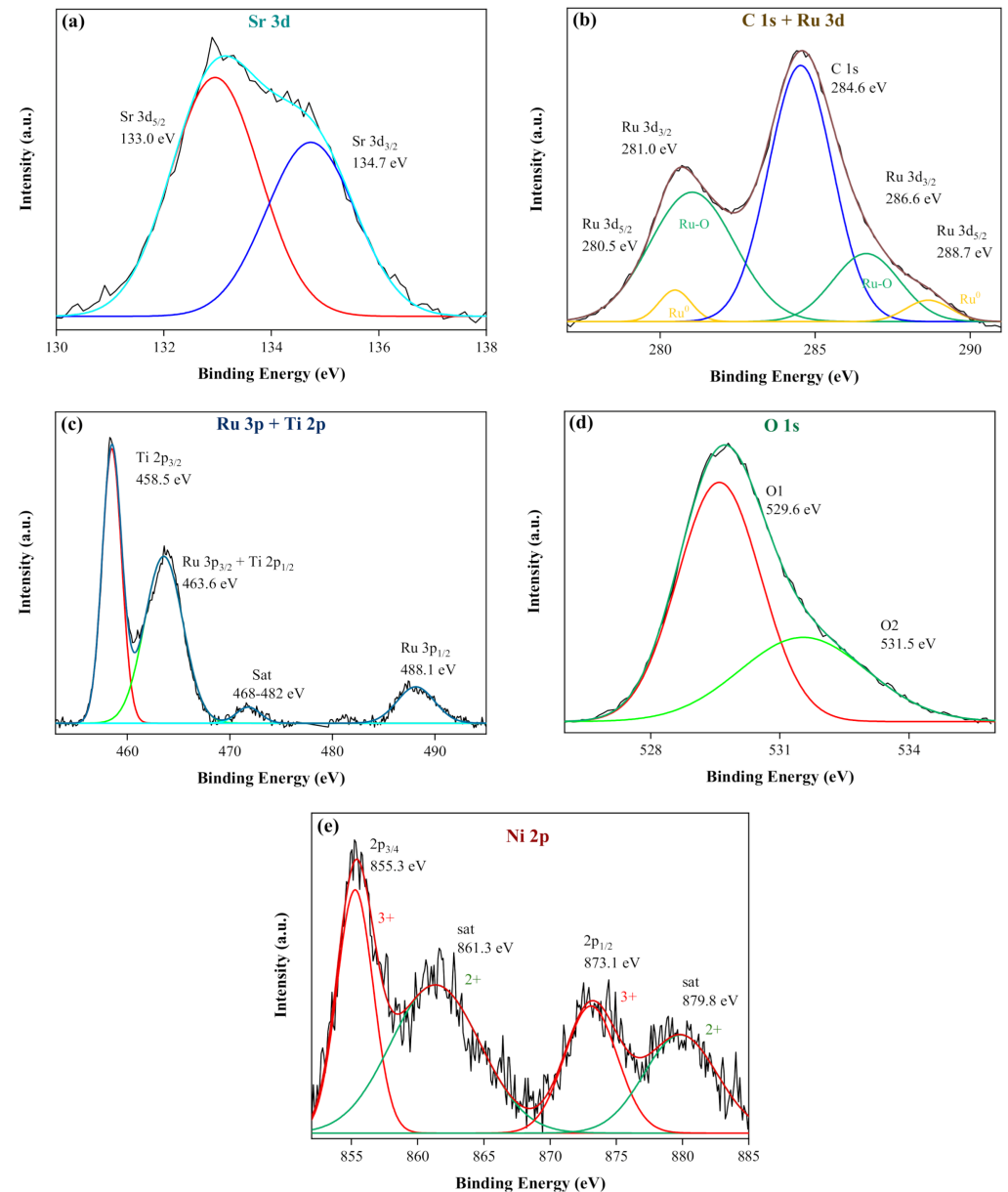

Figure 5. High-resolution XPS spectra of the (a) Sr 3d, (b) C 1s + Ru 3d, (c) Ru 3p + Ti 2p, (d) O 1s, and (e) Ni 2p occupied states recorded for the $\mathrm{SrTiO}_{3}: \mathrm{RuO}_{2}: \mathrm{NiO}$ photocatalyst $(0.8 \mathrm{wt} . \%$ of $\mathrm{Ru}$; [Ru]:[Ni] molar ratio of 1:1), along with the respective fitting and deconvolution curves.

XPS analysis (Figure 5) also attests to the elemental composition of the $\mathrm{SrTiO}_{3}: \mathrm{RuO}_{2}: \mathrm{NiO}$ photocatalyst, consisting of $\mathrm{Ni}, \mathrm{Ru}, \mathrm{Ti}, \mathrm{Sr}$, and $\mathrm{O}$ components, and the absence of any impurity. The spectrum of the Sr $3 d$ occupied state (Figure $5 a$ ) shows the formation of a doublet signal with binding energies of $133.0 \mathrm{eV}$ and $134.7 \mathrm{eV}$, associated with $\mathrm{Sr} 3 \mathrm{~d}_{5 / 2}$ and $\mathrm{Sr} 3 \mathrm{~d}_{3 / 2}$ orbitals, respectively, which is related to the bond between the $\mathrm{Sr}$ atom and the perovskite structure matrix. Although the $\mathrm{C} 1 \mathrm{~s}+\mathrm{Ru} 3 \mathrm{~d}$ combined spectrum (Figure 5b) presents a signal interference associated with the $C 1$ s reference $(284.6 \mathrm{eV})$, from the deconvolution of this spectrum, it is possible to recognize a doublet signal ascribed to two chemically different Ru oxidation states, namely: (i) zero-valent Ru metal, with binding energies at 280.5 and $288.7 \mathrm{eV}$ ( $\mathrm{Ru} 3 \mathrm{~d}_{5 / 2}$ ); and (ii) Ru oxides, with predominant intensity and binding energies at 281.0 and $286.6 \mathrm{eV}\left(\mathrm{Ru} 3 \mathrm{~d}_{3 / 2}\right)$. As regards the Ti element (Figure $5 \mathrm{c}$ ), two peaks related to the $\mathrm{Ti} 2 \mathrm{p}_{3 / 2}$ and $\mathrm{Ti} 2 \mathrm{p}_{1 / 2}$ orbitals were recorded at binding energies of $458.5 \mathrm{eV}$ and $463.6 \mathrm{eV}$, respectively, which are typical values for the Ti oxidation state in the $\mathrm{SrTiO}_{3}$ [38]. However, the intensity peak at $463.6 \mathrm{eV}$ also features an overlapping of the $\mathrm{Ti} 2 \mathrm{p}_{1 / 2}$ and the $\mathrm{Ru} 3 \mathrm{p}_{3 / 2}$ orbitals. On the other hand, the intensity peak at $488.1 \mathrm{eV}$ was only assigned to the $\mathrm{Ru} 3 \mathrm{p}_{1 / 2}$ region. Accordingly, $\mathrm{Ru}$ and Ti elements can affect the ligand screening at charge-transfer configurations [39]. Besides that, the energy region among 468-482 eV might be associated with satellite structures belonging to the main $\mathrm{Ti}$ $2 \mathrm{p}$ and $\mathrm{Ru} 3 \mathrm{p}$ occupied states. From the deconvolution of the $\mathrm{O} 1$ s spectrum (Figure $5 \mathrm{~d}$ ), two peaks were defined, namely $\mathrm{O} 1$ and O2, centered at biding energies of $529.6 \mathrm{eV}$ and $531.5 \mathrm{eV}$, respectively. These peaks can be attributed to metal-oxygen bonds of the $\mathrm{RuO}_{2}$ and $\mathrm{NiO}$ dopants, as well as to defects in the $\mathrm{SrTiO}_{3}$ semiconductor [40-42]. The absence 
of peaks above $531.5 \mathrm{eV}$ may indicate that there is no chemical adsorption of oxygen in the sample [40]. Finally, the Ni 2p spectrum (Figure 5e) shows two spin-orbit doublets and two shakeup satellite peaks, the so-called "sat". Specifically, the two main binding peaks at 855.3 and $873.1 \mathrm{eV}$ and the other two satellite peaks at 861.3 and $879.8 \mathrm{eV}$ were assigned to $\mathrm{Ni}^{3+}$ and $\mathrm{Ni}^{2+}$ species, respectively.

\subsection{Assessment of the Photocatalytic Activity}

\subsubsection{Effect of the Co-Doping Metal Loading}

The main product detected during the gas-phase batch-mode photocatalytic trials was ethanol (Figure S1a). So, it was the only compound thoroughly explored across this paper, conversely to the remaining ones. Furthermore, other products such as hydrogen, carbon monoxide, ethylene, diethyl ether, and water were also identified. However, their concentration continuously remained below the analytic equipment detection limit $(<2 \mathrm{ppm})$. It should also be mentioned that experiments with a Ru content null or higher than $0.8 \mathrm{wt} . \%$ were not performed, since a study reported by Mateo et al. [21] has disclosed that: (i) both $\mathrm{RuO}_{2}$ and $\mathrm{SrTiO}_{3}$ have indispensable roles regarding $\mathrm{CO}_{2}$ methanation, as the first act as the active specie and the second act as the support and the promoter of the photoinduced charge separation; and (ii) and a Ru dosage of $1.2 \mathrm{wt} . \%$ led to lower photocatalyst activity than a $0.4 \mathrm{wt} . \%$ Ru loading, due to the increase of the average $\mathrm{Ru}$ nanoparticle size.

The influence of different $\mathrm{Ru}(0.2,0.4$ and $0.8 \mathrm{wt} . \%)$ and $\mathrm{Ni}([\mathrm{Ru}]:[\mathrm{Ni}]$ molar ratios of 1:0, 1:0.3, 1:1, and 1:2) dosages within the $\mathrm{SrTiO}_{3}$ semiconductor towards the photo-thermalassisted ethanol production is showed in Figure 6. It was found that: (i) the selectivity for ethanol formation was only achieved when Ni was present in the photocatalyst composition; (ii) the ethanol's generation was raised as (a) the Ru content increased, keeping the [Ru]:[Ni] molar ratio in 1:1 and (b) the [Ru]:[Ni] molar ratio augmented until 1:1, using a Ru concentration of $0.8 \mathrm{wt} . \%$; and (iii) a maximum ethanol production of almost $64 \mu \mathrm{mol}$ EtOH g cat $^{-1}$ was attained after $45-$ min reaction (the equivalent to $85 \mu \mathrm{mol} \mathrm{EtOH} \mathrm{gat}^{-1}$ $\left.\mathrm{h}^{-1}\right)$, considering the best catalyst. According to Myint et al. [8], reforming and oxidative dehydrogenation of ethane with $\mathrm{CO}_{2}$ using $\mathrm{FeNi}$ as catalyst shows selectivity to ethylene formation via the $\mathrm{C}-\mathrm{H}$ bond cleavage. So, there is an opportunity to improve ethanol's formation either by ethylene hydration or by inserting $\mathrm{CO}_{2}$-derived $\mathrm{CO}$ into ethane-derived ethylene [43]. Moreover, the $\mathrm{Ni}^{2+}$ species may act as electron traps, which will suppress electron-hole pairs recombination, thus ensuring an effective charge separation [22] and favoring ethanol generation. On the other hand, when $\mathrm{Ni}^{2+}$ is doped in excess, the photocatalytic $\mathrm{CO}_{2}$ reduction reaction could be hindered by the low availability or even the lack of photogenerated electrons, thus decreasing the amount of the reaction by-products. This effect was experimentally checked when the $[\mathrm{Ru}]:[\mathrm{Ni}]$ molar ratio was increased from $1: 1$ to $1: 2$, keeping the Ru content at $0.8 \mathrm{wt} . \%$, as no improvement was spotted regarding the ethanol production yield. Therefore, the photocatalyst composed of a Ru loading of $0.8 \mathrm{wt} . \%$, a [Ru]:[Ni] molar ratio of 1:1, and a reaction time of 45-60 min were selected for the following assays.

Nevertheless, after 45 -min reaction time at $200{ }^{\circ} \mathrm{C}$, the ethanol concentration started to decrease, indicating the formation of other by-products (Figure 6). In fact, the presence of diethyl ether was identified through GC-MS analysis (Figure S1b), but in concentrations below the detection limit of the GC analytical method ( $<0.05 \mathrm{ppm})$. This side-product could have been produced from the ethanol dehydration, according to Equation (1) [44]. A study performed by Oliveira et al. [45] has shown that this reaction was favored for temperatures between 180 and $200^{\circ} \mathrm{C}$, using Cu-Fe/ZSM- 5 catalysts. In comparison, for temperatures above $200{ }^{\circ} \mathrm{C}$, the formation of ethylene was endorsed instead, using ZSM-5 or Fe/Pure ZSM- 5 catalysts.

$$
2 \mathrm{C}_{2} \mathrm{H}_{5} \mathrm{OH} \rightarrow \mathrm{C}_{2} \mathrm{H}_{10} \mathrm{O}+\mathrm{H}_{2} \mathrm{O}
$$




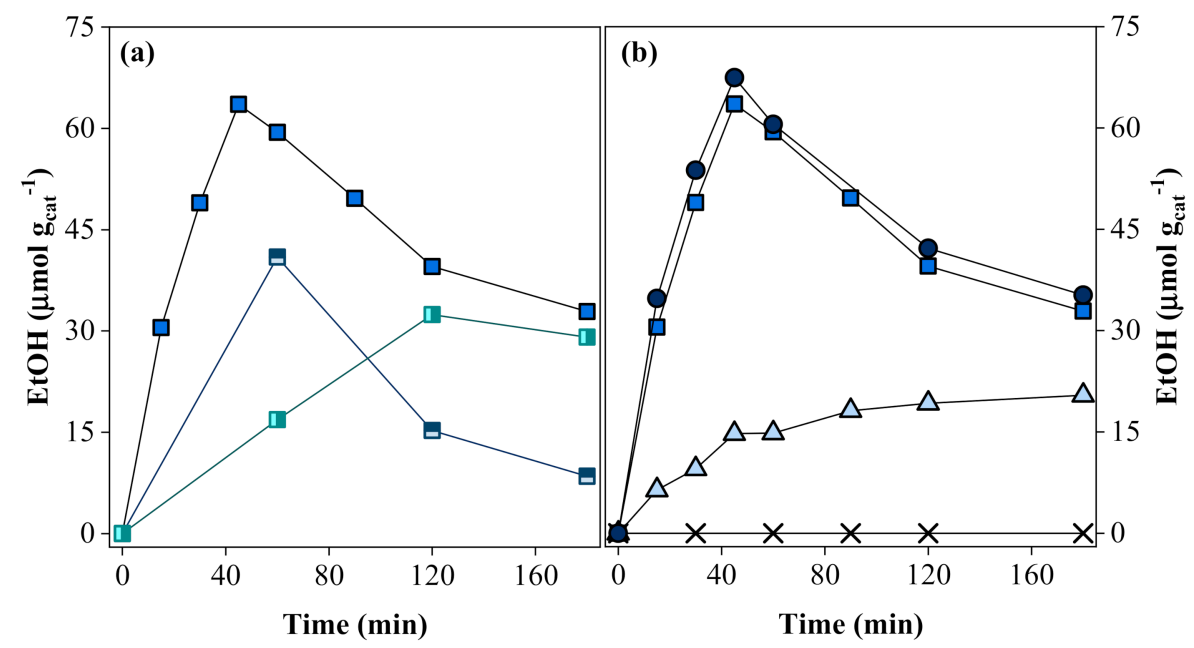

Figure 6. Evolution of the ethanol production from $\mathrm{CO}_{2}$ and $\mathrm{C}_{2} \mathrm{H}_{6}$ as a function of the photoreaction time, using different $\mathrm{SrTiO}_{3}: \mathrm{RuO}_{2}: \mathrm{NiO}$ photocatalyst compositions: (a) Ru loadings of 0.2 wt.\% (- $\square$-), 0.4 wt.\% (-), and 0.8 wt.\% (- $(-)$, keeping a [Ru]:[Ni] molar ratio of 1:1; (b) [Ru]:[Ni] molar ratios of 1:0 (*), 1:0.3 (- - ) $, 1: 1(-\square)$, and 1:2 (- $)$, fixing the Ru content on 0.8 wt. \%. Experimental conditions: $\mathrm{P}_{\mathrm{C}_{2} \mathrm{H}_{6}}=1.01$ bar; $\mathrm{P}_{\mathrm{CO}_{2}}=0.35$ bar; $20 \mathrm{mg}$ of photocatalyst; $\mathrm{T}=200{ }^{\circ} \mathrm{C}$; and $\mathrm{I}=1000 \mathrm{~W} \mathrm{~m}^{-2}$.

\subsubsection{Effect of the Reaction Temperature}

Xie et al. [7] have presented a two-step approach that allows the synthesis of valueadded oxygenates from the reaction of $\mathrm{CO}_{2}$ with ethane, via heterogeneous dehydrogenation/reforming and hydroformylation catalysis, using a combination of $\mathrm{Fe}_{3} \mathrm{Ni} / \mathrm{CeO}_{2}$ (first rector) and Rh-based catalysts (second reactor) at temperatures of $600-800{ }^{\circ} \mathrm{C}$ and $200{ }^{\circ} \mathrm{C}$, respectively. On the other hand, according to a review published by Nair et al. [11], a synergy can be achieved when combining thermal catalysis with photocatalysis, i.e., the hybrid thermal-photocatalysis process, which might permit work at relatively lower temperatures. For instance, despite $\mathrm{CO}_{2}$ methanation usually occurs in temperatures between $300{ }^{\circ} \mathrm{C}$ and $550{ }^{\circ} \mathrm{C}$ [46], Mateo et al. [21] have reported the $\mathrm{CO}_{2}$ methanation at $150{ }^{\circ} \mathrm{C}$ using $\mathrm{SrTiO}_{3}: \mathrm{RuO}_{2}$-driven photocatalysis. Therefore, the temperature must be a crucial parameter to take into consideration in this kind of process.

Figure 7 displays the photothermal influence on the catalytic activity towards ethanol production from the $\mathrm{CO}_{2}$ and $\mathrm{C}_{2} \mathrm{H}_{6}$ reaction, from which it is possible to verify that by increasing the temperature from $50{ }^{\circ} \mathrm{C}$ to $150{ }^{\circ} \mathrm{C}$ the ethanol's production proportionally increased ca. $0.17 \mu \mathrm{mol}$ gcat $^{-1} \mathrm{~h}^{-1}$ per each Celsius degree, considering the timeframe irradiation of $45 \mathrm{~min}$. Distinctively, when the temperature was raised from $150{ }^{\circ} \mathrm{C}$ to $200{ }^{\circ} \mathrm{C}$, the ethanol formation yield significantly increased by about $125 \%$, the equivalent to a specific reaction rate increment of $0.94 \mu \mathrm{mol}$ gcat $^{-1} \mathrm{~h}^{-1}{ }^{\circ} \mathrm{C}^{-1}$. The nonlinear transition in the heating experiments suggests that at $200^{\circ} \mathrm{C}$ there are more molecules with energy values equal to or higher than the reaction activation energy [47]. Therefore, this temperature was chosen to pursue further experiments. It should also be mentioned that the influence of higher temperatures on the reaction rate was not explored due to reactor thermic limitations.

\subsubsection{Effect of the Optical Radiation Wavelength}

In order to evaluate the spectral response of the best photocatalyst, which can be directly linked to the UV-Vis DRS data, different radiation cut-off filters (no filter, $400 \mathrm{~nm}$, $515 \mathrm{~nm}, 550 \mathrm{~nm}, 665 \mathrm{~nm}$ and dark) were used in the thermal-photocatalysis reaction regarding ethanol production. From the UV-Vis DRS data (Figure 2), it was found that the estimated $\mathrm{Eg}$ of the $\mathrm{SrTiO}_{3}: \mathrm{RuO}_{2}: \mathrm{NiO}$ photocatalyst was lower than of the pristine $\mathrm{SrTiO}_{3}$, most likely due to interfacial combination and matched band edges among the different nanomaterials. This means that the electron-hole pairs of the composed photo- 
catalyst, contrary to the pure perovskite, can be generated under visible irradiation by low-energy photons. For that reason, a better photocatalytic activity can be anticipated under visible light.

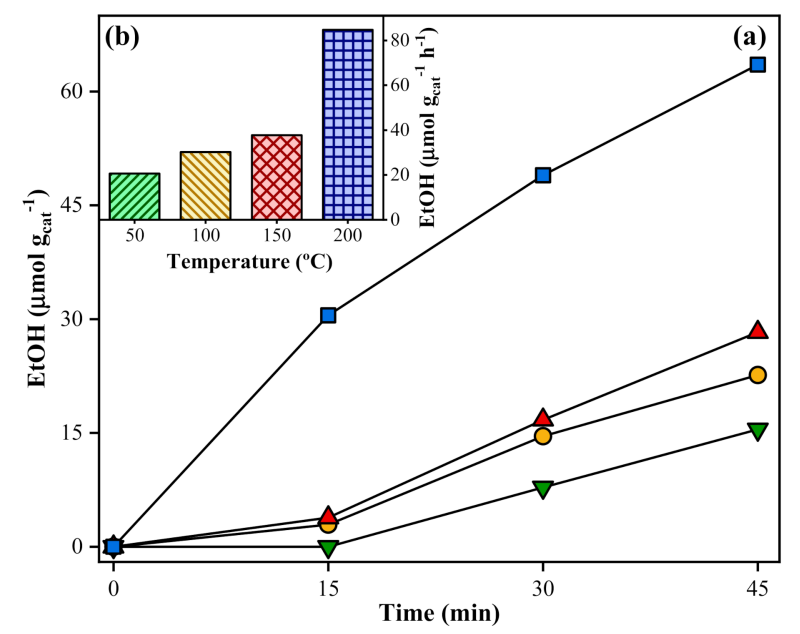

Figure 7. Evolution of the (a) ethanol production from $\mathrm{CO}_{2}$ and $\mathrm{C}_{2} \mathrm{H}_{6}$ as a function of photoreaction's time and the respective (b) reaction rate (for the maximum production), at $50{ }^{\circ} \mathrm{C}(\nabla) ; 100{ }^{\circ} \mathrm{C}\left({ }^{\circ}\right)$; $150^{\circ} \mathrm{C}(\triangle)$, and $200^{\circ} \mathrm{C}(\square)$. Experimental conditions: $20 \mathrm{mg}$ of $\mathrm{SrTiO}_{3}: \mathrm{RuO}_{2}: \mathrm{NiO} ;[\mathrm{Ru}]:[\mathrm{Ni}]=1: 1$ (molar); $\mathrm{Ru}=0.8$ wt. \%; $\mathrm{P}_{\mathrm{C}_{2} \mathrm{H}_{6}}=1.01$ bar; $\mathrm{P}_{\mathrm{CO}_{2}}=0.35$ bar; and $\mathrm{I}=1000 \mathrm{~W} \mathrm{~m}^{-2}$.

From Figure 8, it can be seen that: (i) the control experiment in the dark exhibited negligible ethanol formation; (ii) the photoresponse decreased as the excitation wavelength increased; (iii) the Ru- and Ni-co-doped $\mathrm{SrTiO}_{3}$ showed some residual photocatalytic activity, even exited at wavelengths higher than $655 \mathrm{~nm}$; and (iv) the contribution of the visible radiation $(>400 \mathrm{~nm}$ ) for the global reaction efficiency is about $63 \%$ and, as such, higher than of the UV irradiation. These results, along with the ones from the previous section, showed that the use of heterogeneous thermal-catalysis alone is not able to promote any ethanol generation, and the use of heterogeneous photocatalysis by itself, at temperatures equal to or lower than $150{ }^{\circ} \mathrm{C}$, lead to low reaction yields. So, it can be concluded that a synergy effect between UV-Vis radiation and temperature was attained and the integration of these two parameters is essential aiming at the generation of ethanol.

The difference observed on the ethanol production yield, concerning the trials without filter and using the $400 \mathrm{~nm}$ cut-off filter, can be ascribed to the activity of the $\mathrm{SrTiO}_{3}$ since it is only excited by high-energy UV photons. The results here presented are in good agreement with the UV-vis DRS spectra and the estimated values of the optical band gap energies (Figure 2), which showed that the metals co-doping led to an improved photocatalyst with higher visible light absorption and lower band gap energy. Within the visible spectrum, the catalyst photoresponse was greater in the high-energy region, most probably because noble metal nanoparticles, such as $\mathrm{Ru}$, present insightful optical proprieties due to the strong absorption in the visible light range, called the plasmon band [48]. Furthermore, the absorbance for the wavelengths above $550 \mathrm{~nm}$ can be attributed to the plasmon resonance related to the Ni nanoparticles [20,49]. Taking all the above into account, the photoresponse of the $\mathrm{SrTiO}_{3}: \mathrm{RuO}_{2}: \mathrm{NiO}$ catalyst can be attributed to the $\mathrm{SrTiO}_{3}$ semiconductor excitation, as well as of the Ru and Ni plasmon band, being the latter more efficient towards ethanol production.

The ethanol's production yield obtained in the current work $\left(85 \mu \mathrm{mol} \mathrm{EtOH} \mathrm{g}_{\text {cat }}{ }^{-1}\right.$ $\mathrm{h}^{-1}$ ) is comparable to the others reported in the literature using the same full-length illumination system, i.e., a $300 \mathrm{~W}$ xenon lamp, but through artificial photosynthesis using $\mathrm{CO}_{2}$ and $\mathrm{H}_{2} \mathrm{O}$ as reactants instead. Dai et al. [50] have presented a study regarding the photocatalytic reduction of $\mathrm{CO}_{2}$ at $4{ }^{\circ} \mathrm{C}$ using a PTh $/ \mathrm{Bi}_{2} \mathrm{WO}_{6}$ photocatalyst, under batch mode operation, where the ethanol production yield was $5.1 \mu \mathrm{mol} \mathrm{EtOH} \mathrm{g}$ cat $^{-1} \mathrm{~h}^{-1}$, which 
is 17-fold lower compared to the present study. On the other hand, Cheng et al. [51], using a continuous planar optofluidic microreactor filled with $\mathrm{C}_{2} \mathrm{CdS}-\mathrm{Cu}^{2+} / \mathrm{TiO}_{2}$ photocatalyst at a flow rate of $4 \mathrm{~mL} \mathrm{~min}^{-1}$ and $80^{\circ} \mathrm{C}$, obtained an ethanol production rate of $109 \mu \mathrm{mol}$ $\mathrm{g}_{\mathrm{cat}}{ }^{-1} \mathrm{~h}^{-1}$, which is slightly above $(28 \%)$ to the one attained in this work.

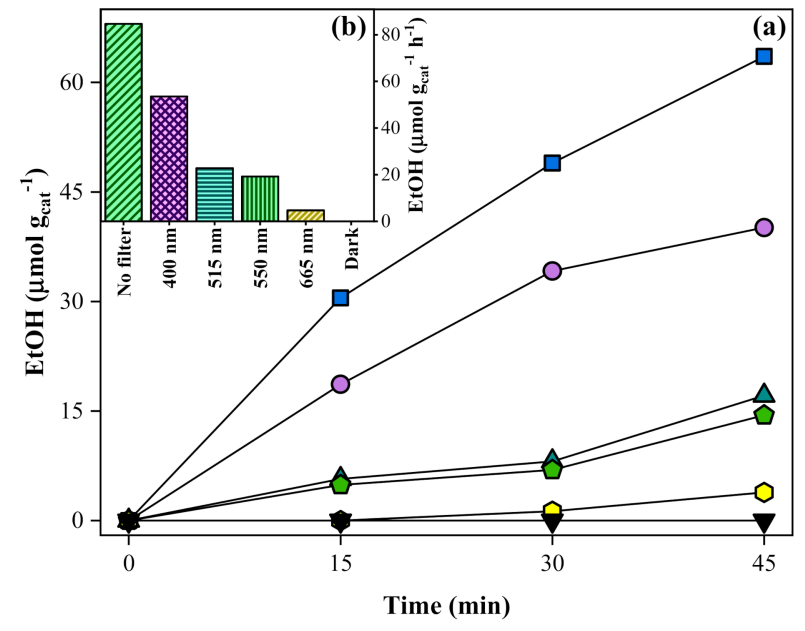

Figure 8. Evolution of the (a) ethanol production from $\mathrm{CO}_{2}$ and $\mathrm{C}_{2} \mathrm{H}_{6}$ over time and the respective (b) reaction rate (for the maximum production), as a measure of the catalyst photoresponse under full illumination $\left(1000 \mathrm{~W} \mathrm{~m}^{-2}\right)$, using filters with different cut-offs: no filter $(\square), 400 \mathrm{~nm}(\mathbf{O}), 515 \mathrm{~nm}(\Delta)$, $550 \mathrm{~nm}(\Delta), 665 \mathrm{~nm}(\boldsymbol{O})$, and dark $(\boldsymbol{\nabla}$, covering the photoreactor with aluminum foil). Experimental conditions: $20 \mathrm{mg}$ of $\mathrm{SrTiO}_{3}: \mathrm{RuO}_{2}: \mathrm{NiO} ;[\mathrm{Ru}]:[\mathrm{Ni}]=1: 1$ (molar); $\mathrm{Ru}=0.8$ wt. \%; $\mathrm{P}_{\mathrm{C}_{2} \mathrm{H}_{6}}=1.01$ bar; $\mathrm{P}_{\mathrm{CO}_{2}}$ $=0.35$ bar; and $\mathrm{T}=200{ }^{\circ} \mathrm{C}$.

\subsubsection{Effect of the Photocatalyst Reuse}

Photocatalyst stability towards ethanol's production by thermal-photocatalysis with $\mathrm{CO}_{2}$ and $\mathrm{C}_{2} \mathrm{H}_{6}$ was investigated during four consecutive batch cycles, using the same $\mathrm{SrTiO}_{3}: \mathrm{RuO}_{2}: \mathrm{NiO}$ sample. Unfortunately, after successive photocatalyst uses, the ethanol's formation rate is significantly decreased ( $>50 \%$ in the 2nd use), reaching a total inhibition right after the 4th use (Figure 9a), indicating poor photocatalytic stability. The TEM images (Figure $9 \mathrm{~b}$ ) clearly exhibit an increase in the opaqueness of the deactivated photocatalyst (Figure 9b.1), when compared to the fresh one (Figure 9b.2), indicating the presence of some impurities onto the catalyst surface, which can block the active sites, thus decreasing the reaction efficiency [52]. Furthermore, molecules able to absorb with multiple bonds, such as $\mathrm{CO}$ and other unsaturated hydrocarbons, can act as a poison for the catalyst because they can interact with metals by means of chemisorption through multiple and reverse bonding [53]. Given these results, the photocatalyst reactivation was tried to reduce the poisoning effect, after the 4th use, by two methods: (i) calcination with $\mathrm{O}_{2}$ from the air, at $350{ }^{\circ} \mathrm{C}$ for $2 \mathrm{~h}$, in an effort to oxidize the salts of the active catalytic materials into active metal oxides; or (ii) $\mathrm{H}_{2}$ flow at $200{ }^{\circ} \mathrm{C}$ for $2 \mathrm{~h}$, in an endeavor to reduce the metals co-doped and remove the elements causing the poisoning. Nevertheless, both reactivation mechanisms did not have the desired effect, obtaining almost null ethanol production yields.

\subsection{Reaction Mechanism Proposal}

In an attempt to understand the potential mechanism of the gas-phase photo-thermalreaction of $\mathrm{CO}_{2}$ with $\mathrm{C}_{2} \mathrm{H}_{6}$, mediated by sunlight, four extra experiments were carried out, adding: (i) $0.2 \mathrm{mmol}$ of $\mathrm{O}_{2}$; (ii) $0.3 \mu \mathrm{mol}$ of $\mathrm{H}_{2} \mathrm{O}$; (iii) $4 \mu \mathrm{mol}$ tetracyanoethylene (TCNE); or (iv) $10 \mu \mathrm{mol}$ of TCNE (Figure 10). 

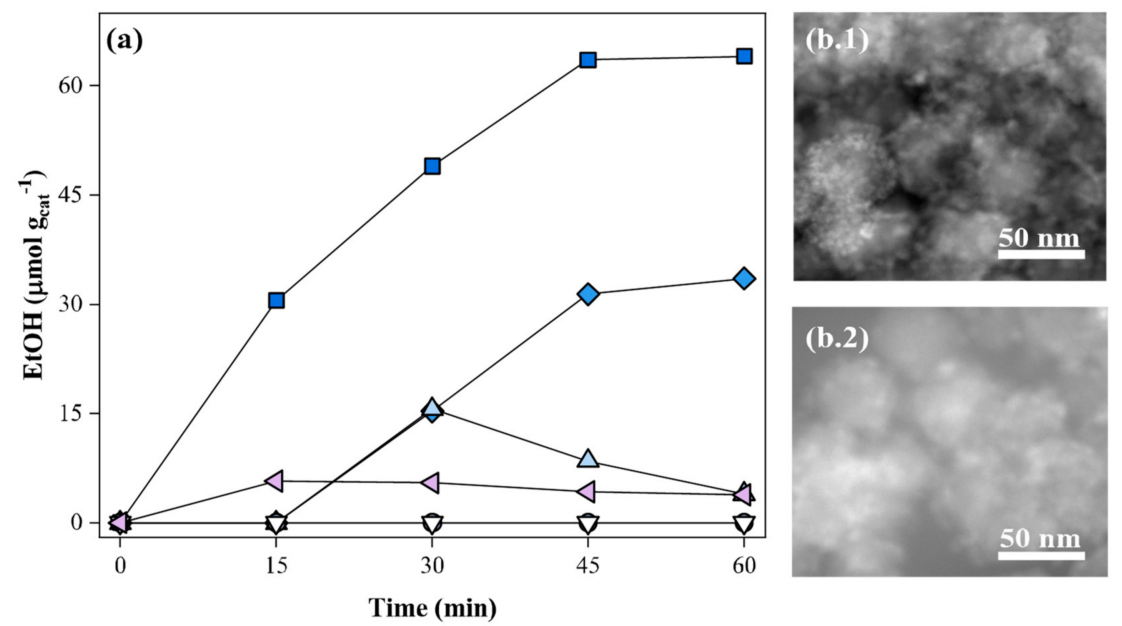

Figure 9. (a) Evolution of the ethanol production from $\mathrm{CO}_{2}$ and $\mathrm{C}_{2} \mathrm{H}_{6}$ as a function of photoreaction time, after (i) 1 cycle $(\square), 2$ cycles $(\diamond), 3$ cycles $(\triangle)$ and 4 cycles $(-O)$ of the photocatalyst use, and (ii) reactivation of the photocatalyst, resulting from the 4 th cycle, with $\mathrm{H}_{2}$ flow $\left(\triangleleft\right.$, at $200{ }^{\circ} \mathrm{C}$ for $2 \mathrm{~h}$ ) or air-driven calcination $\left(\nabla\right.$, at $350{ }^{\circ} \mathrm{C}$ for $2 \mathrm{~h}$ ). Experimental conditions: $20 \mathrm{mg}$ of $\mathrm{SrTiO}_{3}: \mathrm{RuO}_{2}: \mathrm{NiO}$; $[\mathrm{Ru}]:[\mathrm{Ni}]=1: 1$ (molar); $\mathrm{Ru}=0.8$ wt. \%; $\mathrm{P}_{\mathrm{C}_{2} \mathrm{H}_{6}}=1.01$ bar; $\mathrm{P}_{\mathrm{CO}_{2}}=0.35$ bar; $\mathrm{T}=200{ }^{\circ} \mathrm{C}$ and $\mathrm{I}=1000 \mathrm{~W}$ $\mathrm{m}^{-2}$. (b) TEM images of the (.1) fresh and (.2) inactivated photocatalyst (after the 4 th use).

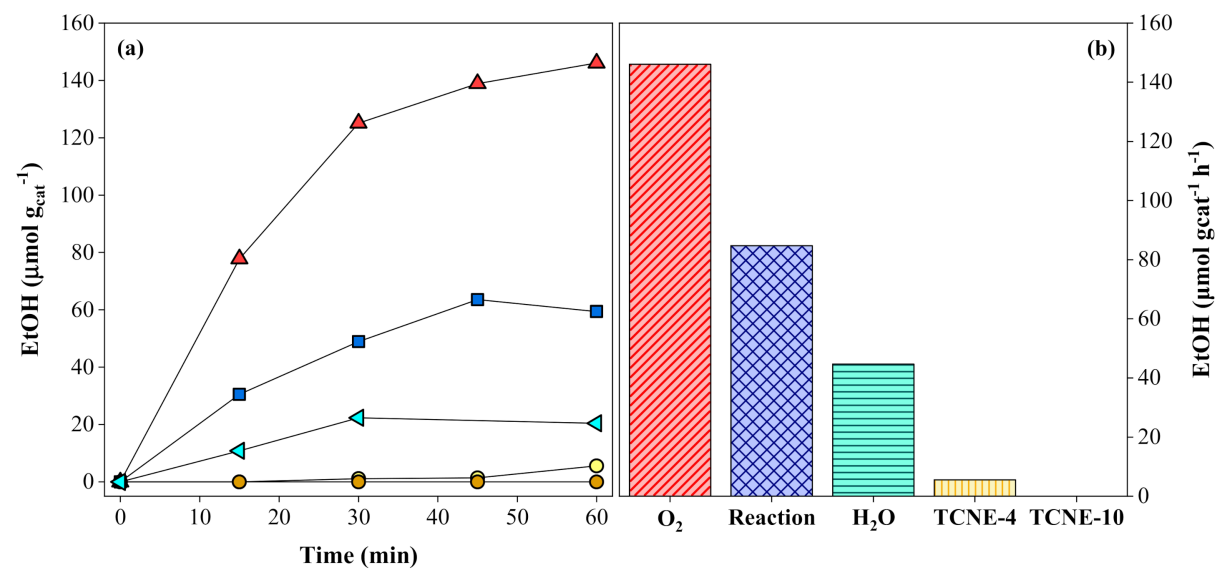

Figure 10. Evolution of the (a) ethanol production from $\mathrm{CO}_{2}$ and $\mathrm{C}_{2} \mathrm{H}_{6}$ as a function of photoreaction's time and the respective (b) reaction rate (for the maximum production), in the absence ( $-\mathrm{r})$ and the presence of electron scavengers: $4(-\circ)$ and $10(--) \mu \mathrm{mol}$ of TCNE; $0.2 \mathrm{mmol}$ of $\mathrm{O}_{2}(--)$; or $0.3 \mu \mathrm{mol}$ of $\mathrm{H}_{2} \mathrm{O}(\triangleleft)$. Experimental conditions: $20 \mathrm{mg}$ of $\mathrm{SrTiO}_{3}: \mathrm{RuO}_{2}: \mathrm{NiO} ;[\mathrm{Ru}]:[\mathrm{Ni}]=1: 1$ (molar); $\mathrm{Ru}=0.8$ wt. \%; $\mathrm{P}_{\mathrm{C}_{2} \mathrm{H}_{6}}=1.01$ bar; $\mathrm{P}_{\mathrm{CO}_{2}}=0.35$ bar; $\mathrm{T}=200{ }^{\circ} \mathrm{C}$ and $\mathrm{I}=1000 \mathrm{~W} \mathrm{~m}^{-2}$.

TCNE was chosen as an electron scavenger since the cyano groups $(\mathrm{CN})$ have lowenergy $\pi^{*}$ orbitals and, consequently, present a high ability to accept electrons [54]. Therefore, it is expected that the chemical reduction reaction of $\mathrm{CO}_{2}$ by the photogenerated electrons at the photocatalyst conduction band is impaired. It was also reported that $\mathrm{CN}^{-}$and $\mathrm{NCO}^{-}$small-molecules can inhibit $\mathrm{CO}_{2}$ reduction and $\mathrm{CO}$ oxidation $[55,56]$. In this way, the oxygenate molecules production is also affected by $\mathrm{CO}$ insertion hindering. Accordingly, Figure 10a discloses that the addition of $4 \mu \mathrm{mol}$ of TCNE severely blocked the ethanol production, being achieved a reaction rate of only $5.6 \mu \mathrm{mol} \mathrm{EtOH} \mathrm{g} \mathrm{cat}^{-1} \mathrm{~h}^{-1}$ (in contrast with the $85 \mu \mathrm{mol} \mathrm{EtOH} \mathrm{g} \mathrm{cat}^{-1} \mathrm{~h}^{-1}$ obtained in the absence of electron scavengers), while the utilization of $10 \mu \mathrm{mol}$ of TCNE causing its total inhibition. This behavior suggests that the reaction mechanism is based on the charge separation into valence band holes and conduction band electrons. 
The addition of water along with the $\mathrm{CO}_{2}$ and $\mathrm{C}_{2} \mathrm{H}_{6}$ diminished the reaction rate by about $47 \%$, as can be seen in Figure $10 \mathrm{~b}$. In this case, the ethanol yield might have been compromised by the preferential production of carbonic acid through the reaction of $\mathrm{CO}_{2}$ with $\mathrm{H}_{2} \mathrm{O}$, according to Equation (2), before the formation of the potential ethanol precursors, $\mathrm{C}_{2} \mathrm{H}_{4}$ and $\mathrm{CO}$.

$$
\mathrm{CO}_{2}+\mathrm{H}_{2} \mathrm{O} \rightarrow \mathrm{H}_{2} \mathrm{CO}_{3}
$$

Even though $\mathrm{O}_{2}$ can act as an electron scavenger in $\mathrm{CO}_{2}$ hydrogenation reaction [57], in the present study, the ethanol yield was increased in its presence, reaching up to a production rate of about 1.7-fold higher $\left(146 \mu \mathrm{mol} \mathrm{EtOH} \mathrm{gcat}{ }^{-1} \mathrm{~h}^{-1}\right)$. This profile suggests that the photogenerated electrons were used by $\mathrm{O}_{2}$ to produce ethanol. According to Bergner et al. [58], the main products obtained from the reaction of oxygen atoms with ethane are ethanol, acetaldehyde, ketene, and CO. Ethanol formation is explained by the inclusion of one $\mathrm{O}\left({ }^{1} \mathrm{D}\right)$ atom into an ethane $\mathrm{C}-\mathrm{H}$ bond, representing a promising path to the chemical complexity [58,59]. Moreover, at low $\mathrm{O}_{2}$ concentrations, the production of $\mathrm{CO}$ and $\mathrm{H}_{2} \mathrm{O}$ by the incomplete combustion of $\mathrm{C}_{2} \mathrm{H}_{6}$ may occur. Hence, the improved ethanol yield can also be linked to $\mathrm{CO}$ generation since two $\mathrm{CO}$ molecules can form $\mathrm{C}_{2} \mathrm{H}_{4}$ and $\mathrm{C}_{2} \mathrm{H}_{5} \mathrm{OH}$, as proposed by Yang et al. [43].

So far, it can be established that the ethanol production is straightly connected with the reaction products of the $\mathrm{CO}_{2}$ and/or $\mathrm{C}_{2} \mathrm{H}_{6}$, taking into account the following pathways [8,60]: (i) dry reforming of $\mathrm{C}_{2} \mathrm{H}_{6}$, producing $\mathrm{H}_{2}$ and $\mathrm{CO}$ via Equation (3); (ii) oxidative dehydrogenation of $\mathrm{C}_{2} \mathrm{H}_{6}$ with $\mathrm{CO}_{2}$, generating $\mathrm{C}_{2} \mathrm{H}_{4}, \mathrm{CO}$ and $\mathrm{H}_{2} \mathrm{O}$, according to Equation (3) and (4); (iii) non-oxidative dehydrogenation, converting $\mathrm{C}_{2} \mathrm{H}_{6}$ into $\mathrm{C}_{2} \mathrm{H}_{4}$ and $\mathrm{H}_{2}$, given by Equation (5); (iv) reverse water gas shift, forming $\mathrm{CO}$ and $\mathrm{H}_{2} \mathrm{O}$, as shown in Equation (6); and (v) cracking of ethane to yield methane, through Equation (7).

$$
\begin{gathered}
\mathrm{C}_{2} \mathrm{H}_{6(\mathrm{~g})}+2 \mathrm{CO}_{2}(\mathrm{~g}) \rightarrow 4 \mathrm{CO}_{(\mathrm{g})}+3 \mathrm{H}_{2}(\mathrm{~g}) \\
\mathrm{C}_{2} \mathrm{H}_{6(\mathrm{~g})}+\mathrm{CO}_{2(\mathrm{~g})} \rightarrow \mathrm{C}_{2} \mathrm{H}_{4}(\mathrm{~g})+\mathrm{CO}_{(\mathrm{g})}+\mathrm{H}_{2} \mathrm{O}_{(\mathrm{l})} \\
\mathrm{C}_{2} \mathrm{H}_{6(\mathrm{~g})} \rightarrow \mathrm{C}_{2} \mathrm{H}_{4(\mathrm{~g})}+\mathrm{H}_{2}(\mathrm{~g}) \\
\mathrm{CO}_{2(\mathrm{~g})}+\mathrm{H}_{2}(\mathrm{~g}) \rightarrow \mathrm{CO}_{(\mathrm{g})}+\mathrm{H}_{2} \mathrm{O}_{(\mathrm{l})} \\
\mathrm{C}_{2} \mathrm{H}_{6(\mathrm{~g})}+2 \mathrm{CO}_{2(\mathrm{~g})} \rightarrow \mathrm{CH}_{4}(\mathrm{~g})+3 \mathrm{CO}_{(\mathrm{g})}+\mathrm{H}_{2} \mathrm{O}_{(\mathrm{l})}
\end{gathered}
$$

Additionally, syngas ( $\mathrm{CO}$ and $\mathrm{H}_{2}$ ) can likewise be used to produce oxygenated organic compounds, such as methanol, ethanol, or mixed higher alcohols, based on the side reactions of the conventional Fischer-Tropsch (FT) process. In other words, following a polymerization mechanism, $\mathrm{CO}$ is activated on metal $(\mathrm{Ru}, \mathrm{Ni}$, Fe or $\mathrm{Co})$ or metal carbide adsorbed $\left(\mathrm{CH}_{\mathrm{x}}\right.$ or $\mathrm{OCH}_{\mathrm{x}}$, with $\left.\mathrm{x}=0-3\right)$ intermediates that will react by a sequence of consecutive coupling to generate $\mathrm{C} 2+$ products $\left(\mathrm{C}_{\mathrm{n}} \mathrm{H}_{m}\right.$ or $\left.\mathrm{C}_{\mathrm{n}} \mathrm{H}_{\mathrm{m}} \mathrm{O}\right)$ [61]. Therefore, ethanol can be obtained from syngas in conformity with Equation (8). Furthermore, as previously mentioned, besides from $\mathrm{CO}$ bond insertion, ethanol production can also be achieved from ethylene hydration, according to Equation (9) [43], which might involve the breakage of the alkene's $\pi$ and $\mathrm{O}-\mathrm{H}$ bonds of the water and the formation of $\mathrm{C}-\mathrm{H}$ and $\mathrm{C}-\mathrm{OH}$ bonds.

$$
\begin{gathered}
2 \mathrm{CO}+4 \mathrm{H}_{2} \rightarrow \mathrm{C}_{2} \mathrm{H}_{5} \mathrm{OH}+\mathrm{H}_{2} \mathrm{O} \\
\mathrm{C}_{2} \mathrm{H}_{4}+\mathrm{H}_{2} \mathrm{O} \rightarrow \mathrm{C}_{2} \mathrm{H}_{5} \mathrm{OH}
\end{gathered}
$$

Building on the information above mentioned and assuming that no methane was generated and $\mathrm{H}_{2} \mathrm{O}$ was detected in the reactor after proper cooling, a theoretical global equation regarding the formation of ethanol from $\mathrm{CO}_{2}$ and $\mathrm{C}_{2} \mathrm{H}_{6}$ is proposed in Equation (10).

$$
3 \mathrm{C}_{2} \mathrm{H}_{6(\mathrm{~g})}+4 \mathrm{CO}_{2}(\mathrm{~g}) \rightarrow 4 \mathrm{CO}_{(\mathrm{g})}+\mathrm{H}_{2} \mathrm{O}_{(\mathrm{l})}+3 \mathrm{C}_{2} \mathrm{H}_{5} \mathrm{OH}_{(\mathrm{g})}
$$

This reaction supposes that 3 moles of ethane react with 4 moles of $\mathrm{CO}_{2}$ to form 4 moles of $\mathrm{CO}$ and 3 moles of ethanol. However, in all the experiments, the $\left[\mathrm{C}_{2} \mathrm{H}_{6}\right]:\left[\mathrm{CO}_{2}\right]$ molar 
ratio was 3:1, which might explain the non-appearance of $\mathrm{CO}$ among the reaction products. Moreover, given the high initial concentration of $\mathrm{C}_{2} \mathrm{H}_{6}$ comparatively to $\mathrm{CO}_{2}$, the nonoxidative dehydrogenation could have been favored. Notwithstanding, this hypothesis cannot be accurately confirmed since the $\mathrm{C}_{2} \mathrm{H}_{4}$ content was always below the $\mu \mathrm{GC}$ detection limit (<2 ppm). On the other hand, the fact that ethanol production was increased when $\mathrm{O}_{2}$ was present (Figure 10) might be related to the hydroformylation stem from the generated ethylene [8].

Based on the results discussed, a coherent mechanism for hybrid $\mathrm{SrTiO}_{3}: \mathrm{RuO}_{2}: \mathrm{NiO}$ catalyst towards the production of ethanol (EtOH) from $\mathrm{CO}_{2}$ and $\mathrm{C}_{2} \mathrm{H}_{6}$ is here proposed (Figure 11). As previously evidenced, near $60 \%$ of the ethanol has been produced under visible light illumination, where electron excitation in $\mathrm{SrTiO}_{3} \mathrm{UV}$-vis absorption is limited to the UV region. Hence, this photocatalyst's photoresponse in the visible region can be attributed to the $\mathrm{RuO}_{2}$ and $\mathrm{NiO}$ nanoparticles' optical absorption deposited on the $\mathrm{SrTiO}_{3}$. In this case, co-doping causes a charge difference resulting in the distribution of electrons across the $\mathrm{Ru}-\mathrm{O}$ and $\mathrm{Ni}-\mathrm{O}$ covalent bands. Meanwhile, photoinduced electrons $\left(\mathrm{e}^{-}\right)$are easily promoted from the valence band (VB) to the conduction band (CB), creating holes $\left(h^{+}\right)$in the VB. The excited electrons in the CB of the $\mathrm{SrTiO}_{3}$ are continuously transferred to adjacent atoms to maintain the neutrality of the metal oxide nanoparticles, that phenomenon was reported by the Schottky barrier theory. The synthesis gas is produced via $\mathrm{CO}_{2-}$ assisted hydrogenation, in which case the electron reduces $\mathrm{CO}_{2}$ into intermediates, $\mathrm{CO}_{2-}$ and $\mathrm{HCOO}$, with an uncertain transition state. Then photoinduced electrons in the metal oxide sites combined with $\mathrm{H}^{+}$reduce these intermediates, resulting in $\mathrm{H}_{2}$ and $\mathrm{CO}$. On the other hand, holes in the $\mathrm{VB}$ of $\mathrm{SrTiO}_{3}$ are captured by surface-bound $\mathrm{OH}^{-}$on the semiconductor to form ${ }^{\circ} \mathrm{OH}$ radicals. These hydroxyl radicals can abstract a hydrogen atom from ethane to generate ethyl radicals, probably bonded to the surface. Simultaneously, ethane reforming occurs via the activated $\mathrm{C}-\mathrm{H}$ bond and subsequent formation of the alkoxides and ethyl, which are adsorbed and oxidized via $\mathrm{h}^{+}$or ${ }^{\circ} \mathrm{OH}$ to an intermediate radical, converting to ethylene. Finally, these reaction intermediates when coupling ethyl and hydroxyl radicals, or through oxidation or hydration of ethylene result in ethanol formation.

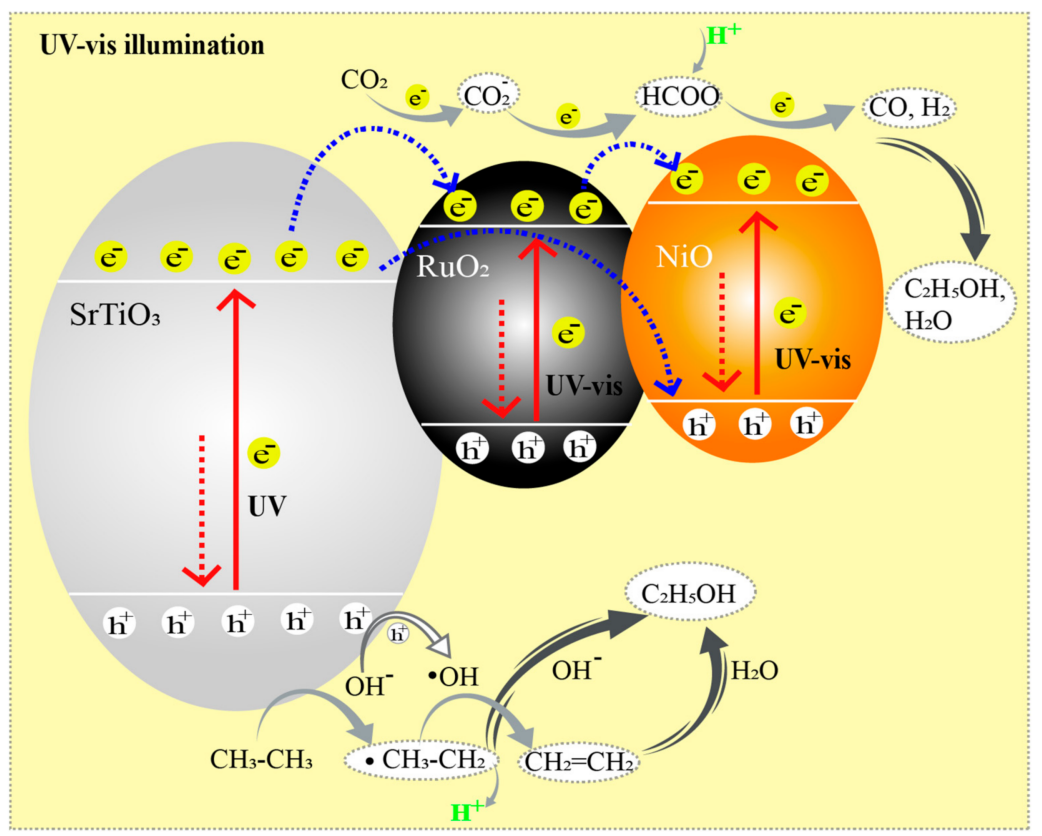

Figure 11. Possible reaction pathway and mechanism towards ethanol production, from $\mathrm{CO}_{2}$ and $\mathrm{C}_{2} \mathrm{H}_{6}$, on the surface of the hybrid $\mathrm{SrTiO}_{3}: \mathrm{RuO}_{2}: \mathrm{NiO}$ catalyst, by means of solar-driven heterogeneous thermo-photocatalysis. 


\section{Materials and Methods}

\subsection{Chemicals}

Ruthenium chloride $\left(\mathrm{RuCl}_{3} \cdot \mathrm{H}_{2} \mathrm{O}\right)$ with $36.96 \%(w / w)$ purity was obtained from Johnson Matthey, London, UK. Nickel chloride $\left(\mathrm{NiCl}_{2}\right)$ with $99.99 \%(w / w)$ purity was provided by Aldrich, Saint Louis, MO, USA. Strontium titanate $\left(\mathrm{SrTiO}_{3}\right)$ nanopowder $(<100 \mathrm{~nm}$ particle size) with $\geq 99 \%(w / w)$ purity was supplied by Sigma-Aldrich, Saint Louis, MO, USA. Ethylene glycol $\left(\mathrm{HOCH}_{2} \mathrm{CH}_{2} \mathrm{OH}\right)$ with $99 \%(w / v)$ purity was purchased from SigmaAldrich, MO, USA. Ethanol absolute and acetone, $99.8 \%$ and $99.5 \%(v / v)$, respectively, were supplied by Panreac AppliChem, Spain. Tetracyanoethylene with $98 \%(w / w)$ purity was acquired from Aldrich, Saint Louis, MO, USA. All chemicals were used as received without further purification. Ultrapure water was obtained from a Milli-Q IQ 7000 ultrapure-water system $\left(18.2 \mathrm{M} \Omega \mathrm{cm}\right.$ at $25^{\circ} \mathrm{C}$, Merck, Darmstadt, Germany). For gas chromatography and reactants feeding system, the gas bottles of helium $5.0(99.999 \%)$, nitrogen $2.8(99.8 \%)$, oxygen $2.5(99.5 \%)$, hydrogen $5.0(99.999 \%)$, carbon dioxide $4.5(99.995 \%)$, ethane $3.5(99.95 \%)$ and synthetic air K 5.0 (99.999\%) were supplied by Linde, Dublin, Ireland.

\subsection{Preparation of the $\mathrm{SrTiO}_{3}: \mathrm{RuO}_{2}: \mathrm{NiO}$ Photocatalyst}

Initially, different amounts of $\mathrm{RuCl}_{3} \cdot \mathrm{H}_{2} \mathrm{O}$ (to obtain a final Ru content of $0.2,0.4$ and $0.8 \mathrm{wt} . \%$ ) were added to a suspension of $\mathrm{SrTiO}_{3}$ nanopowder in ethylene glycol $\left(5 \mathrm{mg} \mathrm{mL}{ }^{-1}\right)$, previously obtained by sonication at $700 \mathrm{~W}$ for $30 \mathrm{~min}$, where $\mathrm{Ru}^{3+}$ was impregnated and reduced by reflux method at $180^{\circ} \mathrm{C}$, for $8 \mathrm{~h}$, under continuous stirring (1000 rpm), as reported by Mateo et al. [21]. Then, $\mathrm{SrTiO}_{3}-\mathrm{Ru}$ nanoparticles were recovered by vacuum filtration (Nylon membranes, Membrane Solution MS ${ }^{\circledR}$, Seattle, WA, USA) and further washed with a mixture of ultrapure water $(1 \mathrm{~L})$ and acetone $(200 \mathrm{~mL})$, and dried in an oven at $100{ }^{\circ} \mathrm{C}$ for 2 -h. The actual concentration of $\mathrm{Ru}^{3+}$ in the $\mathrm{SrTiO}_{3}-\mathrm{Ru}$ nanopowder was estimated by ICP-OES, whose values are depicted in Table S1.

Afterward, $\mathrm{NiCl}_{2}$ was impregnated in $\mathrm{SrTiO}_{3}-\mathrm{Ru}$ nanoparticles (with $\mathrm{Ru}: \mathrm{Ni}$ molar ratios of 1:0, 1:0.3, 1:1, and 1:2, based on the ICP-OES results). In this sense, $200 \mathrm{mg}$ of $\mathrm{SrTiO}_{3}-\mathrm{Ru}$ nanopowder was dispersed in $10 \mathrm{~mL}$ of ultrapure water by sonication at $700 \mathrm{~W}$ for $15 \mathrm{~min}$. Then, this dispersion was dried at $70{ }^{\circ} \mathrm{C}$, under slow stirring, and when the solution volume halved, $5 \mathrm{~mL}$ of a $\mathrm{NiCl}_{3}$ solution $\left(\mathrm{NiCl}_{3}\right.$ dissolved in ultrapure water) was added dropwise. The slow mixing was kept until complete evaporation of the water. Subsequently, $\mathrm{SrTiO}_{3}-\mathrm{Ru}-\mathrm{NiCl}_{2}$ nanopowder was reduced under $\mathrm{H}_{2}$ atmosphere $(100 \mathrm{~mL}$ $\min ^{-1}$ ) at $20{ }^{\circ} \mathrm{C}$ for $2 \mathrm{~h}$. Lastly, $\mathrm{SrTiO}_{3}-\mathrm{Ru}$-Ni nanoparticles were oxidized by calcination at $350{ }^{\circ} \mathrm{C}$ for $3 \mathrm{~h}$, under ambient atmosphere, to obtain the nanostructured $\mathrm{SrTiO}_{3}-\mathrm{RuO}_{2}-\mathrm{NiO}_{2}$ photocatalyst. The preparation procedure is summarized in Figure 1. The Ni concentration in the catalyst was also assessed by ICP-OES (Table S1).

\subsection{Photocatalyst Characterization}

The final photocatalyst composition in terms of Ru and Ni metals was determined by inductively coupled plasma-optical emission spectrometry (ICP-OES, Varian 715-ES, CA, USA) after aqua regia extraction. The best photocatalyst was also characterized by Raman spectroscopy, X-ray photoelectron spectroscopy (XPS), transition electron microscopy (TEM), energy-dispersive $X$-ray spectroscopy (EDS) mapping, $X$-ray diffraction (XRD), and UV-vis diffuse reflectance spectroscopy (DRS).

Raman spectroscopy analyses were carried out in a Horiba, Kyoto, Japan, Jobin YvonLabram HR UV-Visible-NIR (200-1600 nm) Raman Microscope Spectrometer, using a $632 \mathrm{~nm}$ laser as the excitation source. XPS was recorded on a SPECS spectrometer (SPECS, Berlin, Germany) with a Phoibos 1509 MCD detector using a non-monochromatic X-ray source ( $\mathrm{Al}$ and $\mathrm{Mg}$ ) operating at $200 \mathrm{~W}$, to compensate for any kind of charging effect, being the $\mathrm{C} 1 \mathrm{~s}$ binding energy peak at $284.6 \mathrm{eV}$ used as a reference. TEM images and EDS mapping were recorded in a Philips CM300 FEG system (Philips, Amsterdam, The Netherlands) with $100 \mathrm{kV}$ operating voltage. Dried samples were prepared onto a carbon-coated copper TEM grid. Lattice parameter measurements for $\mathrm{SrTiO}_{3}$ co-doped 
were performed by XRD analysis. The photocatalyst's powder XRD pattern was recorded using a Philips (Amsterdam, The Netherlands) X'PERT diffractometer, equipped with a proportional detector and a secondary graphite monochromator. Data were collected stepwise over the $2 \theta$ ranges with an accumulation time of $20 \mathrm{~s} \mathrm{step}^{-1}$. UV-vis DRS analysis in the range of 200-800 $\mathrm{nm}$ was recorded on a Cary 5000 spectrophotometer from Varian (CA, USA).

\subsection{Experimental Procedure}

Thermo-photo-assisted experiments were carried out in batch operation mode at gas-phase, using a photocatalytic apparatus entailing four main parts (see Figure S2): (i) a $51 \mathrm{~mL}$ pressurized cylindrical reaction vessel made of quartz glass and equipped with a temperature controlling system $\left(\leq 200{ }^{\circ} \mathrm{C}\right)$ and a pressure gauge ( $\leq 2 \mathrm{bar}$ ); (ii) a $1000 \mathrm{~W} \cdot \mathrm{m}^{-2}$ mercury-xenon lamp (visible light type) connected to a Lightningcure Spot LC8 light source (Hamamatsu, Japan), reproducing the solar light spectrum within $400<$ $\lambda<700 \mathrm{~nm}$; (iii) reactants feeding system with a regulator of high pressure $\left(2^{\circ}\right.$ stadium); and (iv) an analytical system composed of one micro gas chromatograph (GC) provided with a thermal conductivity detector (TCD) and a GC provided with a flame ionization detector (FID). The $\mu$ GC-TCD (Agilent 490 MicroGC, CA, USA) was equipped with two channels, both with independent TCD, using Ar as the carrier gas. One channel had a MolSieve 5A column (MS5A $10 \mathrm{~m}$ heated, injector, backflush) to analyze $\mathrm{H}_{2}$. The other had a Pore Plot Q (PPQ $10 \mathrm{~m}$ heated, injector, backflush) column to analyze $\mathrm{CO}_{2}, \mathrm{CO}$, and $\mathrm{C}_{1}-\mathrm{C}_{4}$ hydrocarbons. The GC-FID (Varian 3900, CA, USA) was equipped with an HP-5 column (30 m length, $0.25 \mathrm{~mm}$, inner diameter, and $0.25 \mu \mathrm{m}$ film) and using argon as the carrier gas to analyze oxygenates, such as EtOH and diethyl ether.

The cylindrical quartz vessel (Figure S2) had an input and an output sealed by vacuum fittings and syringe valves (SV) provided with push buttons (PB), to allow the sampling of the gas from the reactor headspace using a gas syringe. The reactor also had an internal pressure meter (PM), working up to 2 bar. The heating system was composed of a fiberglass heating tape (FHT), placed around the reactor, and a temperature probe (TP), located between the reactor's end and the FHT, both connected to a digital thermostat temperature controller (DTTC), able to control the temperature up to $200{ }^{\circ} \mathrm{C}$.

Before each experiment, the reactor was washed five times with ultrapure water and dried at $200{ }^{\circ} \mathrm{C}$. After cooling until room temperature, $20 \mathrm{mg}$ of the photocatalyst, with the desired composition, was introduced in the reactor's center. Then, the reactor inlet was connected to a gas bottle and a purging with $\mathrm{C}_{2} \mathrm{H}_{6}$ was performed for $5 \mathrm{~min}$, keeping both valves open. Afterward, the reactor's outlet was closed until the pressure increased by 2 bar and successively opened to eliminate any residual gas. This process was repeated 4 times. In the sequence, the intended gaseous proportions of $\mathrm{C}_{2} \mathrm{H}_{6}$ and $\mathrm{CO}_{2}$ were fed to the reactor with the outlet valve closed, reaching a pressure of 1.35 bar. Subsequently, the DTTC was connected to the reactor and programmed for $50{ }^{\circ} \mathrm{C}, 100{ }^{\circ} \mathrm{C}, 150{ }^{\circ} \mathrm{C}$ or $200{ }^{\circ} \mathrm{C}$. Once the desired temperature was reached, 2 min were awaited until the pressure stabilized. Lastly, the initial sample was collected immediately before the reaction was initiated by turning on the illumination.

\section{Conclusions}

The heterogeneous thermo-photocatalysis induced by $\mathrm{SrTiO}_{3}$ co-doped with $\mathrm{RuO}_{2}$ and $\mathrm{NiO}$ has shown itself a promising process to convert $\mathrm{CO}_{2}$, the main greenhouse gas, and $\mathrm{C}_{2} \mathrm{H}_{6}$, the second main constituent of shale gas, into $\mathrm{EtOH}$, a value-added chemical, under simulated sunlight at moderate temperature. In contrast with some traditional techniques that use these compounds at temperatures between 300 and $900{ }^{\circ} \mathrm{C}$. The optimized $\mathrm{SrTiO}_{3}: \mathrm{RuO}_{2}: \mathrm{NiO}$ thermo-photocatalyst $(0.8 \mathrm{wt} . \% \mathrm{Ru}$; [Ru]:[Ni] molar ratio of 1:1) exhibited the highest photocatalytic activity at $200{ }^{\circ} \mathrm{C}$, under batch operation mode, achieving a maximum ethanol's production rate of $85 \mu \mathrm{mol} \mathrm{EtOH} \mathrm{g} \mathrm{cat}^{-1} \mathrm{~h}^{-1}$, starting from a gas-phase mixture with a $\left[\mathrm{CO}_{2}\right]:\left[\mathrm{C}_{2} \mathrm{H}_{6}\right]$ molar ratio of ca. 1:3. 
The catalyst photoresponse towards EtOH generation can mainly be ascribed to the visible photons since UV radiation contributed only about $37 \%$ to the global reaction efficiency. This behavior is in good agreement with UV-Vis DRS characterization, where it was found that the double doping process increased the photocatalyst's visible light absorption by decreasing its optical band gap energy. The absence of radiation and $\mathrm{NiO}$ on the photocatalyst's surface resulted in no ethanol formation, and temperatures below $200{ }^{\circ} \mathrm{C}$ considerably decreased the reaction's yield by more than $55 \%$. Regrettably, the photocatalyst showed poor stability, as the decay on ethanol's production was significant right after a 2 nd use $(>50 \%)$, reaching total inhibition after a 4th use. Mechanistic studies adding electron scavenger molecules suggested that the photogenerated electron-hole pairs' charge separation indeed contributed to the thermo-photoconversion reaction. Moreover, it was inferred that the ethane non-oxidative dehydrogenation pathway towards $\mathrm{EtOH}$ synthesis was favored, considering that the molar ratio between $\mathrm{C}_{2} \mathrm{H}_{6}$ and $\mathrm{CO}_{2}$ was 3 to 1 , when it should have been 3 to 4 , taking into account the general equation proposed in this exploratory paper. In any case, more insights are needed regarding the feasibility of this process towards the intensification of the reaction between these underutilized gases aiming at the production of solar fuels.

Supplementary Materials: The following are available online at https:/ /www.mdpi.com/article/ 10.3390/catal11040461/s1, Figure S1: Mass spectra of the by-products obtained from the thermophotocatalytic reaction of $\mathrm{CO}_{2}$ with $\mathrm{C}_{2} \mathrm{H}_{6}$ over $\mathrm{SrTiO}_{3}: \mathrm{RuO}_{2}: \mathrm{NiO}$ catalyst, namely: (a) ethanol; and (b) diethyl ether. Experimental conditions: $20 \mathrm{mg}$ of $\mathrm{SrTiO}_{3}: \mathrm{RuO}_{2}: \mathrm{NiO}$; [Ru]:[Ni] = 1:1 (molar); $\mathrm{Ru}=$ 0.8 wt. \%; $\mathrm{P}_{\mathrm{C} 2 \mathrm{H} 6}=1.01$ bar; $\mathrm{P}_{\mathrm{CO} 2}=0.35$ bar; $\mathrm{T}=200{ }^{\circ} \mathrm{C}$ and $\mathrm{I}=1000 \mathrm{~W} \mathrm{~m}^{-2}$. Equipment: Agilent 5973 inert Gas Chromatograph/Mass Spectrometer; electronic ionization, positive ion mode, Figure S2: Schematic representation of the batch photocatalytic system, Table S1: Concentration of Ru and $\mathrm{Ni}$ elements (wt.\%) in the photocatalyst assessed by ICP-OES analysis (after aqua regia extraction).

Author Contributions: Conceptualization, J.A. and H.G.; data curation, L.O.P. and T.F.C.V.S.; investigation, L.O.P.; methodology, J.A. and H.G.; resources, H.G.; supervision, R.J.E.M., R.A.R.B., V.J.P.V., T.F.C.V.S. and H.G.; validation, L.O.P.; visualization, L.O.P. and T.F.C.V.S.; writing-original draft, L.O.P. and T.F.C.V.S.; writing-review \& editing, J.A., R.J.E.M., R.A.R.B., V.J.P.V., T.F.C.V.S. and H.G. All authors have read and agreed to the published version of the manuscript.

Funding: This work was financially supported by the Base Funding-UIDB/50020/2020 of the Associate Laboratory LSRE-LCM—funded by national funds through FCT/MCTES (PIDDAC). Larissa O. Paulista also wants to acknowledge for her doctoral fellowship (reference SFRH/BD/137639/2018), supported by FCT. Tânia F. C. V. Silva and Vítor J. P. Vilar acknowledge the FCT Individual Call to Scientific Employment Stimulus 2017 (CEECIND/01386/2017 and CEECIND/01317/2017, respectively). Josep Albero and Hermenegildo García are also grateful to the Spanish Ministry of Science and Innovation (RTI2018-098237-CO2-R1 and Severo Ochoa), Generalitat Valencia (Prometeo 2017/083) and European Union's Horizon 2020 research and innovation programme under grant agreement No 862453, project FlowPhotochem, by financial contribution.

Conflicts of Interest: The authors declare no conflict of interest.

\section{References}

1. Chang, X.; Wang, T.; Gong, J. $\mathrm{CO}_{2}$ photo-reduction: Insights into $\mathrm{CO}_{2}$ activation and reaction on surfaces of photocatalysts. Energy Environ. Sci. 2016, 9, 2177-2196. [CrossRef]

2. Li, M.; Li, P.; Chang, K.; Wang, T.; Liu, L.; Kang, Q.; Ouyang, S.; Ye, J. Highly efficient and stable photocatalytic reduction of $\mathrm{CO}_{2}$ to $\mathrm{CH}_{4}$ over Ru loaded $\mathrm{NaTaO}_{3}$. Chem. Commun. 2015, 51, 7645-7648. [CrossRef] [PubMed]

3. Niu, F.; Shen, S.; Zhang, N.; Chen, J.; Guo, L. Cobaloxime coenzyme catalyzing artificial photosynthesis for hydrogen generation over CdS nanocrystals. Appl. Catal. B-Environ. 2016, 199, 134-141. [CrossRef]

4. Noureldin, M.M.B.; Elbashir, N.O.; Gabriel, K.J.; El-Halwagi, M.M. A Process Integration Approach to the Assessment of $\mathrm{CO}_{2}$ Fixation through Dry Reforming. ACS Sustain. Chem. Eng. 2015, 3, 625-636. [CrossRef]

5. Börner, A.; Franke, R. Hydroformylation: Fundamentals, Processes, and Applications in Organic Synthesis; John Wiley \& Sons: Hoboken, NJ, USA, 2016.

6. Franke, R.; Selent, D.; Börner, A. Applied Hydroformylation. Chem. Rev. 2012, 112, 5675-5732. [CrossRef] 
7. Xie, Z.; Xu, Y.; Xie, M.; Chen, X.; Lee, J.H.; Stavitski, E.; Kattel, S.; Chen, J.G. Reactions of $\mathrm{CO}_{2}$ and ethane enable CO bond insertion for production of C3 oxygenates. Nat. Commun. 2020, 11, 1-8. [CrossRef]

8. Myint, M.; Yan, B.; Wan, J.; Zhao, S.; Chen, J.G. Reforming and oxidative dehydrogenation of ethane with $\mathrm{CO}_{2}$ as a soft oxidant over bimetallic catalysts. J. Catal. 2016, 343, 168-177. [CrossRef]

9. Skoufa, Z.; Heracleous, E.; Lemonidou, A.A. On ethane ODH mechanism and nature of active sites over NiO-based catalysts via isotopic labeling and methanol sorption studies. J. Catal. 2015, 322, 118-129. [CrossRef]

10. Shen, Z.; Liu, J.; Xu, H.; Yue, Y.; Hua, W.; Shen, W. Dehydrogenation of ethane to ethylene over a highly efficient Ga $\mathrm{O}_{3} / \mathrm{HZSM} 5$ catalyst in the presence of $\mathrm{CO}_{2}$. Appl. Catal. A Gen. 2009, 356, 148-153. [CrossRef]

11. Nair, V.; Muñoz-Batista, M.J.; Fernández-García, M.; Luque, R.; Colmenares, J.C. Thermo-Photocatalysis: Environmental and Energy Applications. ChemSusChem 2019, 12, 2098-2116. [CrossRef]

12. Tu, W.; Zhou, Y.; Zou, Z. Photocatalytic Conversion of $\mathrm{CO}_{2}$ into Renewable Hydrocarbon Fuels: State-of-the-Art Accomplishment, Challenges, and Prospects. Adv. Mater. 2014, 26, 4607-4626. [CrossRef]

13. Barber, J.; Tran, P.D. From natural to artificial photosynthesis. J. R. Soc. Interface R. Soc. 2013, 10. [CrossRef]

14. Ola, O.; Maroto-Valer, M.M. Review of material design and reactor engineering on $\mathrm{TiO}_{2}$ photocatalysis for $\mathrm{CO}_{2}$ reduction. $J$. Photochem. Photobiol. C 2015, 24, 16-42. [CrossRef]

15. Luo, C.; Zhao, J.; Li, Y.; Zhao, W.; Zeng, Y.; Wang, C. Photocatalytic $\mathrm{CO}_{2}$ reduction over $\mathrm{SrTiO}_{3}$ : Correlation between surface structure and activity. Appl. Surf. Sci. 2018, 447, 627-635. [CrossRef]

16. Shao, K.; Wang, Y.; Iqbal, M.; Lin, L.; Wang, K.; Zhang, X.; He, M.; He, T. Modification of Ag nanoparticles on the surface of $\mathrm{SrTiO}_{3}$ particles and resultant influence on photoreduction of $\mathrm{CO}_{2}$. Appl. Surf. Sci. 2018, 434, 717-724. [CrossRef]

17. Kang, H.W.; Lim, S.N.; Park, S.B. Co-doping schemes to enhance $\mathrm{H}_{2}$ evolution under visible light irradiation over $\mathrm{SrTiO}_{3}: \mathrm{Ni} / \mathrm{M}$ ( $\mathrm{M}=$ La or Ta) prepared by spray pyrolysis. Int. J Hydrogen Energy 2012, 37, 5540-5549. [CrossRef]

18. Kang, H.W.; Park, S.B. $\mathrm{H}_{2}$ evolution under visible light irradiation from aqueous methanol solution on $\mathrm{SrTiO} / 3: \mathrm{Cr} / \mathrm{Ta}$ prepared by spray pyrolysis from polymeric precursor. Int. J Hydrogen Energy 2011, 36, 9496-9504. [CrossRef]

19. Takata, T.; Domen, K. Defect engineering of photocatalysts by doping of aliovalent metal cations for efficient water splitting. J. Phys. Chem. C 2009, 113, 19386-19388. [CrossRef]

20. Niishiro, R.; Kato, H.; Kudo, A. Nickel and either tantalum or niobium-codoped $\mathrm{TiO}_{2}$ and $\mathrm{SrTiO}_{3}$ photocatalysts with visible-light response for $\mathrm{H}_{2}$ or $\mathrm{O}_{2}$ evolution from aqueous solutions. Phys. Chem. Chem. Phys. 2005, 7, 2241-2245. [CrossRef]

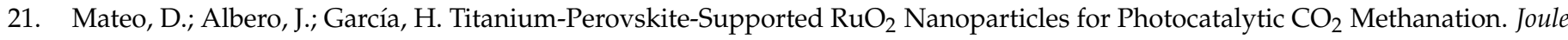
2019, 3, 1949-1962. [CrossRef]

22. Ola, O.; Mercedes Maroto-Valer, $\mathrm{M}$. Role of catalyst carriers in $\mathrm{CO}_{2}$ photoreduction over nanocrystalline nickel loaded TiO photocatalysts. J. Catal. 2014, 309, 300-308. [CrossRef]

23. Li, Q.-S.; Domen, K.; Naito, S.; Onishi, T.; Tamaru, K. Photocatalytic synthesis and photodecomposition of ammonia over SrTiO 3 and $\mathrm{BaTiO}_{3}$ based catalysts. Chem. Lett. 1983, 12, 321-324. [CrossRef]

24. Kubelka, P.; Munk, F. A contribution to the optics of pigments. Z. Tech. Phys. 1931, 12, 193.

25. Zhang, C.; Jiang, N.; Xu, S.; Li, Z.; Liu, X.; Cheng, T.; Han, A.; Lv, H.; Sun, W.; Hou, Y. Towards high visible light photocatalytic activity in rare earth and $\mathrm{N}$ co-doped $\mathrm{SrTiO}_{3}$ : A first principles evaluation and prediction. RSC Adv. 2017, 7, 16282-16289. [CrossRef]

26. Ramya, E.; Rao, M.V.; Jyothi, L.; Rao, D.N. Photoluminescence and nonlinear optical properties of transition metal (Ag, Ni, Mn) doped ZnO nanoparticles. J. Nanosci. Nanotechnol. 2018, 18, 7072-7077. [CrossRef]

27. García-Ramírez, P.; Ramírez-Morales, E.; Solis Cortazar, J.C.; Sirés, I.; Silva-Martínez, S. Influence of ruthenium doping on UVand visible-light photoelectrocatalytic color removal from dye solutions using a $\mathrm{TiO}_{2}$ nanotube array photoanode. Chemosphere 2021, 267, 128925. [CrossRef]

28. Mondal, A.; Giri, N.; Sarkar, S.; Majumdar, S.; Ray, R. Tuning the photocatalytic activity of ZnO by TM (TM = Fe, Co, Ni) doping. Mat. Sci. Semicon. Proc. 2019, 91, 333-340. [CrossRef]

29. Jia, A.; Su, Z.; Lou, L.-L.; Liu, S. Synthesis and characterization of highly-active nickel and lanthanum co-doped SrTiO 3 . Solid State Sci. 2010, 12, 1140-1145. [CrossRef]

30. Mitsui, T.; Nouma, S.; Landolt, B. Numerical Data and Functional Relation in Science and Technology: Crystal and Solid State Physics; New Series, Group 2I; Springer: Berlin/Heidelberg, Germany, 1982.

31. Glazer, A. Simple ways of determining perovskite structures. Acta Crystallogr. A 1975, 31, 756-762. [CrossRef]

32. Al-Shomar, S. Investigation the effect of doping concentration in Ruthenium-doped $\mathrm{TiO}_{2}$ thin films for solar cells and sensors applications. Mater. Res. Express. 2020, 7, 036409. [CrossRef]

33. Langford, J.I.; Wilson, A. Scherrer after sixty years: A survey and some new results in the determination of crystallite size. J. Appl. Crystallogr. 1978, 11, 102-113. [CrossRef]

34. Scherrer, P. Bestimmung der inneren Struktur und der Größe von Kolloidteilchen mittels Röntgenstrahlen. Kolloidchem. Ein Lehrb. 1912, 387-409. [CrossRef]

35. Chekuri, R.D.; Tirukkovalluri, S.R. Synthesis of cobalt doped titania nano material assisted by gemini surfactant: Characterization and application in degradation of Acid Red under visible light irradiation. Sajog S. Afr. J. Chem. Eng. 2017, 24, 183-195. [CrossRef]

36. Yahmadi, B.; Kamoun, O.; Alhalaili, B.; Alleg, S.; Vidu, R.; Kamoun Turki, N. Physical Investigations of (Co, Mn) Co-Doped ZnO Nanocrystalline Films. Nanomaterials 2020, 10, 1507. [CrossRef] 
37. Álvarez, M.A.; Bobadilla, L.F.; Garcilaso, V.; Centeno, M.A.; Odriozola, J.A. $\mathrm{CO}_{2}$ reforming of methane over Ni-Ru supported catalysts: On the nature of active sites by operando DRIFTS study. J. CO2 Util. 2018, 24, 509-515. [CrossRef]

38. Vasquez, R.P. SrTiO 3 by XPS. Surf. Sci. Spectra 1992, 1, 129-135. [CrossRef]

39. Guedes, E.; Abud, F.; Martins, H.; Abbate, M.; Jardim, R.; Mossanek, R. Role of Ti-Ru interaction in $\mathrm{SrTi}_{0.5} \mathrm{Ru}_{0.5} \mathrm{O}_{3}$ : $\mathrm{Physical}$ properties, x-ray spectroscopy, and cluster model calculations. Phys. Rev. B 2019, 100. [CrossRef]

40. Mahala, C.; Basu, M. Nanosheets of $\mathrm{NiCO}_{2} \mathrm{O}_{4} / \mathrm{NiO}$ as efficient and stable electrocatalyst for oxygen evolution reaction. ACS Omega 2017, 2, 7559-7567. [CrossRef]

41. Mayer, B.; Neumann, M. XPS satellites in transition metal oxides. J. Electron. Spectrosc. 1996, 81, 63-67. [CrossRef]

42. Shi, J.; Hui, F.; Yuan, J.; Yu, Q.; Mei, S.; Zhang, Q.; Li, J.; Wang, W.; Yang, J.; Lu, J. Ru-Ti oxide based catalysts for HCl oxidation: The favorable oxygen species and influence of Ce additive. Catalysts 2019, 9, 108. [CrossRef]

43. Yang, K.D.; Lee, C.W.; Jin, K.; Im, S.W.; Nam, K.T. Current status and bioinspired perspective of electrochemical conversion of $\mathrm{CO}_{2}$ to a long-chain hydrocarbon. J. Phys. Chem. Lett. 2017, 8, 538-545. [CrossRef]

44. Zhang, M.; Yu, Y. Dehydration of ethanol to ethylene. Ind. Eng. Chem. 2013, 52, 9505-9514. [CrossRef]

45. Oliveira, T.K.R.; Rosset, M.; Perez-Lopez, O.W. Ethanol dehydration to diethyl ether over Cu-Fe/ZSM-5 catalysts. Catal. Commun. 2018, 104, 32-36. [CrossRef]

46. Schaaf, T.; Grünig, J.; Schuster, M.R.; Rothenfluh, T.; Orth, A. Methanation of $\mathrm{CO}_{2}$-storage of renewable energy in a gas distribution system. Energy Sustain. Soc. 2014, 4, 1-14. [CrossRef]

47. Saladin, F.; Alxneit, I. Temperature dependence of the photochemical reduction of $\mathrm{CO}_{2}$ in the presence of $\mathrm{H}_{2} \mathrm{O}$ at the solid/gas interface of $\mathrm{TiO}_{2}$. J. Chem. Soc. Faraday Trans. 1997, 93, 4159-4163. [CrossRef]

48. Moores, A.; Goettmann, F. The plasmon band in noble metal nanoparticles: An introduction to theory and applications. New J. Chem. 2006, 30, 1121-1132. [CrossRef]

49. Devi, S.; Korake, P.; Achary, S.N.; Gupta, N.M. Genesis of enhanced photoactivity of CdS/Nix nanocomposites for visible-lightdriven splitting of water. Int. J. Hydrogen Energy 2014, 39, 19424-19433. [CrossRef]

50. Dai, W.; Xu, H.; Yu, J.; Hu, X.; Luo, X.; Tu, X.; Yang, L. Photocatalytic reduction of $\mathrm{CO}_{2}$ into methanol and ethanol over conducting polymers modified $\mathrm{Bi}_{2} \mathrm{WO}_{6}$ microspheres under visible light. Appl. Surf. Sci 2015, 356, 173-180. [CrossRef]

51. Cheng, M.; Yang, S.; Chen, R.; Zhu, X.; Liao, Q.; Huang, Y. Visible light responsive CdS sensitized TiO 2 nanorod array films for efficient photocatalytic reduction of gas phase $\mathrm{CO}_{2}$. Mol. Catal. 2018, 448, 185-194. [CrossRef]

52. Panayotov, D.; Kondratyuk, P.; Yates, J. Photooxidation of a mustard gas simulant over $\mathrm{TiO}_{2}-\mathrm{SiO}_{2}$ mixed-oxide photocatalyst: Site poisoning by oxidation products and reactivation. Langmuir 2004, 20, 3674-3678. [CrossRef]

53. Argyle, M.D.; Bartholomew, C.H. Heterogeneous catalyst deactivation and regeneration: A review. Catalysts 2015, 5, 145-269. [CrossRef]

54. Fatiadi, A.J. Addition and cycloaddition reactions of tetracyanoethylene (TCNE) in organic chemistry. Synthesis 1987, 1987, 749-789. [CrossRef]

55. Wang, V.C.C.; Can, M.; Pierce, E.; Ragsdale, S.W.; Armstrong, F.A. A Unified Electrocatalytic Description of the Action of Inhibitors of Nickel Carbon Monoxide Dehydrogenase. J. Am. Chem. Soc. 2013, 135, 2198-2206. [CrossRef] [PubMed]

56. Bachmeier, A.; Hall, S.; Ragsdale, S.W.; Armstrong, F.A. Selective Visible-Light-Driven $\mathrm{CO}_{2}$ Reduction on a p-Type Dye-Sensitised NiO Photocathode. J. Am. Chem. Soc. 2014, 179-191. [CrossRef]

57. Dey, G.R. Chemical Reduction of $\mathrm{CO}_{2}$ to Different Products during Photo Catalytic Reaction on TiO 2 under Diverse Conditions: An Overview. J. Nat. Gas Chem. 2007, 16, 217-226. [CrossRef]

58. Bergner, J.B.; Öberg, K.I.; Rajappan, M. Oxygen atom reactions with $\mathrm{C}_{2} \mathrm{H}_{6}, \mathrm{C}_{2} \mathrm{H}_{4}$, and $\mathrm{C}_{2} \mathrm{H}_{2}$ in ices. Astrophys. J. 2019, 874, 115. [CrossRef]

59. DeMore, W.B. Reaction of $\left.\mathrm{O}^{1} \mathrm{D}\right)$ with hydrocarbons in liquid argon. J. Phys. Chem. 1969, 73, 391-395. [CrossRef]

60. Zumdahl, S.S. Chemical Principles, 6th ed.; D. C. Heath: Lexington, MA, USA, 1992.

61. Albero, J.; Peng, Y.; Garcia, H. Photocatalytic $\mathrm{CO}_{2}$ reduction to C2+ products. ACS Catal. 2020, 10, 5734-5749. [CrossRef] 